Historic, Archive Document

Do not assume content reflects current scientific knowledge, policies, or practices. 


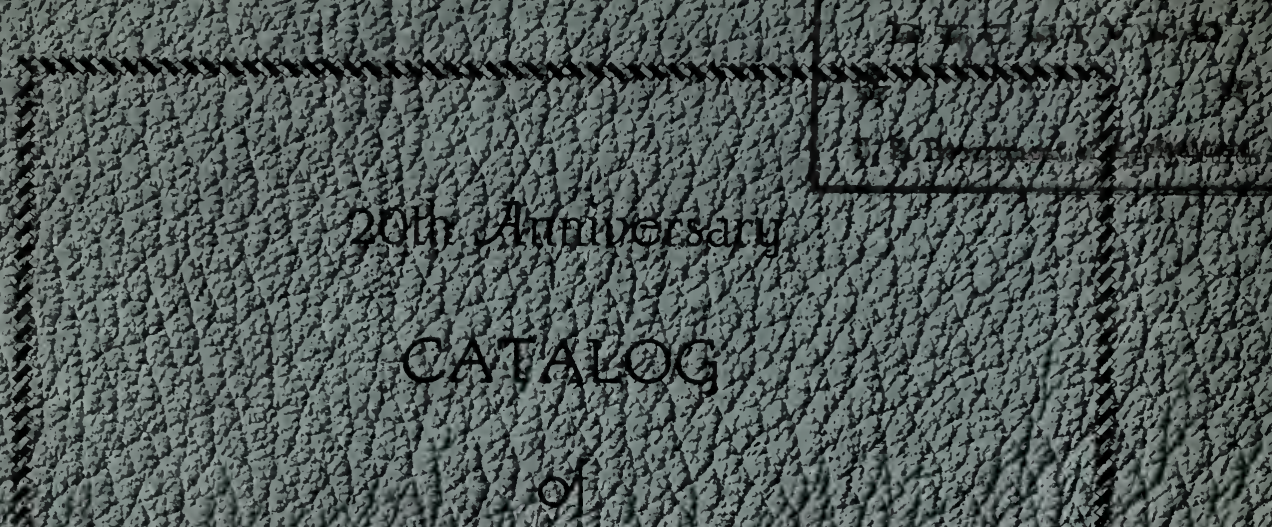

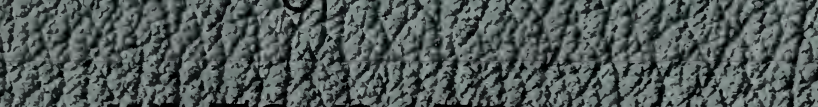

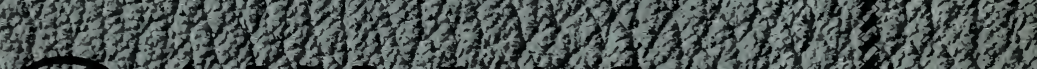

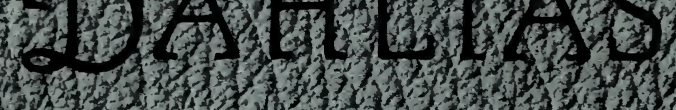

\section{(6, 4 -}

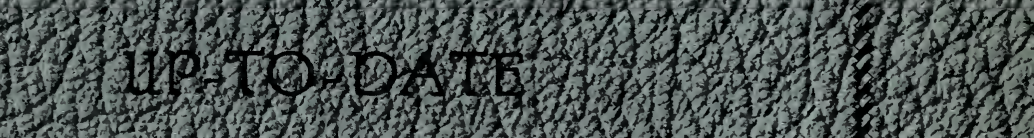

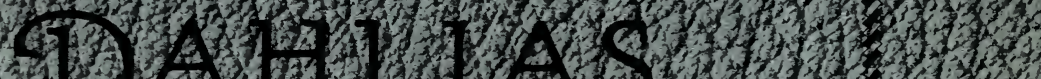

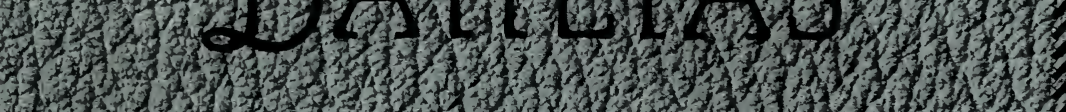

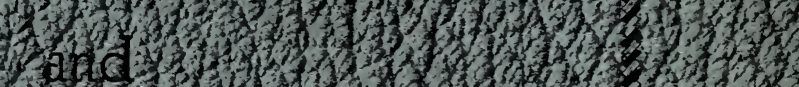

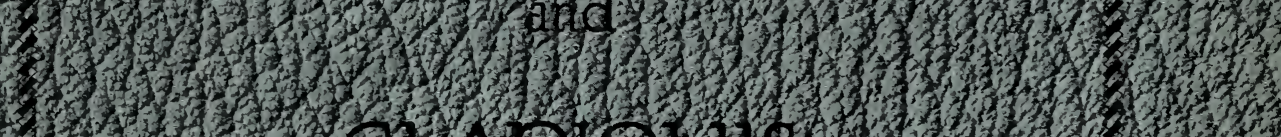

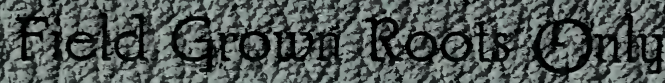

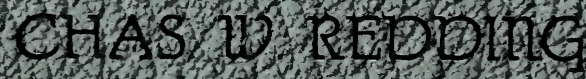

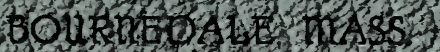





\section{Therent Division}

\section{TO MY CUSTOMERS:-}

\section{GREETINGS.}

It is with a great deal of pleasure that I present to you my 1930 catalog, it being my twentieth anniversary of growing the dahlia commercially.

There has been many wonderful improvements in the dahlia in that time. The immense, beautiful varieties produced today little resemble those of 1910 . The cactus dahlia was but little known, there were no hybrid cactus or other hybrid types, and there were but a few giant decoratives or paeony flowered dahlias at that time.

The beautiful colors, wonderful formations and immense size has made it the most popular flower of today. No other flower will produce such a wealth of blooms, and do so from three to four months.

I wish you all could see my fields in bloom, especially my new seedlings. There are hundrds of wonderful new varieties that are well worth seeing, but of course only a few of the very best will ever be named and listed as there are so many wonderful new varieties being introduced each year.

The dahlia gardens are located in the southern part of the town of Plymouth, but our mail address is Bournedale.

Thanking you all for your generous patronage in the past and wishing you every success in the future, I am,

\section{Yours very truly,}

Chas. W. Redding.

Member of

American Dahlia Society,

The Dahlia Society of New England,

The Dahla Society of San Francisco,

Dahlia Society of Southern California,

The American Gladiolus Society,

New England Gladiolus Society,

Massachusetts Horticultural Society. 
spraying or dusting. A nicotine spray or dust will control these pests. They should be applied during the warmest part of the day and when the sun is shining. Start spraying or dusting when the plants are quite small as the pests are very small and do a lot of harm before discovered. It is better to get there first. A few good sprayings early will save a lot of trouble later.

\section{DAHLIA STUNT}

After many years of growing and experimenting with the dahlia I do not find any dahlia disease that we need to worry about. The dahlia stunt is a disease only in as far as lack of vitality is concerned, and that is easily over come by planting only good healthy stock and taking good care of them. The greater part of the stunt is caused by insects that sap the vitality of the plants. The balance is lack of vitality caused by several minor things, as by planting over propagated stock, green plants or roots, by planting old mother roots, roots beginning to decay, roots badly dried up, or roots that have been over fed and forced to the limit to produce immense blooms for exhibition. By planting only strong healthy stock and carefully spraying the plants one should seldom find a stunted plant in their gardens. Once in a while a plant will suddenly stop growing and die and the cause will generally be found by digging up the root. Some insect or a mole has caused the trouble or the root has rotted, probably had started to rot at the time of planting but was not noticed.

\section{CUT FLOWERS}

When cutting flowers for decorations or exhibition, they should be cut late in the evening or early morning as they will keep longer if cut before the sun reaches them. Cut good long stems as the plant will be all the better for the pruning. Place in cold water in a cool place, removing all the lower leaves. When using a little salt in the water will help them to stay fresh longer. Also another method is to dip the stems into scalding water a few minutes and then place them in cool water until wanted. Remove all blooms from the plants when faded.

\section{EXHIBITION FLOWERS}

Allow only one stalk to grow to each root, and allow only one bud to grow on each branch. If only a few extra large flowers are wanted for exhibition, disbudding should be started as soon as the first buds appear. This will send all the strength of the new orowth to the lower branches or laterals. making vigorous growth that will produce longer stems before the buds start to grow. When these laterals begin to put out flower buds new shoots will begin to grow at every pair of leaves. These should be all removed except the last pair nearest the stalk. When the flower on each lateral has been removed the branch should be cut back to the new shoots which will then put out new laterals and flowers. After this allow all growth to develop, it will help in the maturing of the roots. When this method is used allow only four to six branches to grow on each plant, pinching out any others as they appear. It will be well to work a little fertilizer into the soil about the plants every two or three weeks.

\section{DAHLIAS FROM SEED}

Growing dahlias from seed is very interesting. All the wonderful new dahlias are produced in this way. There is a great deal of pleasure watching each flower open, knowing that every one will be different, and hoping each new one will be a beauty. The usual way recommended for planting dahlia seed is in doors or under glass, transplanting to small pots or flats when large enough to handle easily. They should be gradually hardened off before planting out in gardens. June first is plenty early.

I discarded this method as I found it required a great deal of time and labor and I was not satisfied with the results. Several years ago I started planting my seed in the open ground June first, quite thickly in rows three feet apart. There they grow undisturbed, except for cultivation, until digging time. I plant about 10,000 seed each year and find $75 \%$ bloom before frost. Those showing promise, large double flowers, having good stems and good colors are kept for further trial the following season as also are those that do not bloom. No fertilizers are used and but very little the second year. The third year only the very finest are kept and then they are cared for in the regular way. By this method and carefully selecting of seed year after year from only the largest and finest varieties I have produced many wonderful varieties, such as Mrs. Chas. W. Redding, Elizabeth (Lizzie) Ford, Oh-Henry, Red Sox, Miss Cape Cod, Worlds Champion, The Co-ed, Super Six and many others that are well worth growing. When saving your own seed, save only from the best as mentioned above. It hardly pays to try for good seed until late in September or early in October as the large double dahlias do not set seed until late when they begin to show open centers. When nurchasir - seed, the ruestion of 
whether to buy hand pollenized seed or those crossed by the bees, one must decide for oneself. My experience with seed has proved to be $100 \%$ in favor of the bees. Experementing with high priced Californian seed has been very costly and a total loss. I have never produced a dahlia from these seed that I have kept after the second year. The many letters I receive from customers telling me of their terrible dissappointments from their high priced, hand pollenized seed shows plainly that they are having the same results that I have had. California may be able to grow more seed than we can in the east but not better. I believe the best results can be had by selecting one's own seed or purchasing them as near by as possible. I greatly doubt that $10 \%$ of the new wonderful varieties introduced during the last few years are produced from hand pollenized seed.

\section{PROPAGATING}

I am not in favor of propagating by cuttings as it can be very easily over done to the injury of the stock. Many fine varieties have been so weakened by wholesale propagating that it is impossible to get good reliable stock of them. It is a quick way of increasing the stock of the new varieties and so is often over done. However many believe in it and probably no great harm would be done if not forced to the limit. To propagate by cuttings, start the clumps under glass in early spring and when sprouts are long enough to handle easily they should be cut off and rooted in sand. Water well at first and then keep them just wet enough to prevent wilting. When rooted transplant to small pots. It requires two or three weeks. Plants should be gradually accustomed to a cooler temperature before planting out.

\section{DIGGING THE ROOTS}

After frost has killed the plants they should be cut off close to the ground. Allow them to remain a few days before digging. Select a warm sunny day, digging them early and drying them most of the day in the sun before storing. Care must be taken when handling the roots as they are easily broken and are then a total loss. An unheated, frost proof, well ventilated cellar is the ideal place for storing, where they can be put away without packing. Heated cellars are more difficult as roots must be packed in some dry material, as sand or peat to keep from drying. A great many roots are lost by drying out each year. It is well to look them over during the winter and supply moisture if needed. A cold room off the cellar is often a good place.

\section{SEPARATING THE ROOTS}

This should be done in the spring a short time before planting. Each clump should be examined before cutting to find where it is best to cut. The eyes or sprouts are situated where the roots and stalk meet, and should be so separated that a small part of the stalk is attached to each root. If sprouts have not started they can be put in a light, warmer place and wet, when they will soon start to grow. Roots vary greatly in their manner of growth, some are very open and easily separated, others solid clumps that are harder to cut. These are easier to separate if cut in halves by cutting down through the stalk. One naturally wants to get as many from each clump as possible, so must study each clump to find how to cut to the best advantage. There are several kinds of knives and tools used for separating the clumps. I prefer a good pair of pruning shears although a good sharp knife is also needed at times. When cut they should be kept in a cool place until planting. When cutting it is a good plan to locate the old or mother root and throw it away.

\section{FIELD GROWN ROOTS}

I sell only field grown roots and guarantee each root to grow and prove true to name. It is my wish to give perfect satisfaction to every customer and request them to let me know when results are not as guaranteed. I can not make good a mistake if I do not know about it.

\section{ORDER EARLY}

Order as early as possible. Many of the newer varieties are sold out early in the season. Roots can be sent any distance with perfect safety. All roots are delivered free at catalog prices unless otherwise stated. Please use order sheet when ordering. I do not substitute unless requested.

\section{REMITTANCES}

Payment must accompany with order or before time of shipment. Remittances can be made in the form of P. O. Money Order, Express Money Order, Registered Letter or Personal Check. Small amounts will be accepted in U. S. postage stamps.

\section{FREE ROOTS}

When ordering, if customers will send me the names of a few friends who they think would be interested in my catalogue, I will remember them with some extras for their kindness. 


\section{LABELS}

So many customers write me for labels that I keep a large stock on hand to supply them. These are sold in lots of 100 for $\$ 1.00$ or $\$ 3.50$ for 1000 . Postage paid.

\section{NAMED COLLECTIONS}

For the benefit of customers not familiar with names of dahlia and wish me to make the selection for them, I make up the following collections. They are made up of the very best I can give for the price, and have always given perfect satisfaction. You are sure of good value and will be found listed at about double the price in the catalog. Names of varieties must be left to me, but can be had from any class or classes desired. Each root is labeled with name and is guaranteed. Prices as follows, $1 \mathrm{doz}$. all different for $\$ 1.00, \$ 2.00, \$ 3.00, \$ 5.00$ or $\$ 10.00$. One half of any collection at the same rate.

\section{UNNAMED VARIETIES}

In the handling of the roots many become mixed in one way or another and can not be sold as named varieties. These are all good growing roots. Any one wishing a good display of fine dahlias at low cost will find these very satisfactory.' Price $\$ 3.00$ for 100 roots. Customer must pay the postage or express on these roots.

\section{DAHLIA SEED}

I sell but one grade of seed, selected from only very fine, double varieties. The same selected seed that I use myself. The stock is some what limited as I require a great many for my own plantings. The balance I sell for $\$ 1.00$ per package of 100 seed, good count. 


\section{Decorative Dahlias}

ALBERT WARD 6ft. Fisher \& Mason. An enormous flower on extremely long, bare stems, somewhat pendant. Color a very fine light purple. One of the largest.

$\$ 1.00$

AMERICAN WONDER, R. 5ft. Redding. A large fine flower of distinct form and color. Stems somewhat pendant. Color tyrian-rose at the center, shading to tyrianpink on the outer petals.

$\$ 2.50$

AMERICAN GIRL 5ft. Redding. Large rose-like flower. Color cerise, edged pure white. Stems good.

$\$ 1.00$

AMUN RA.

$6 \mathrm{ft}$.

Seal.

A giant flower of original form and color. Stems erect. Color combination as in a glorious setting sun. Copper, orange and gold, deepening to bronze at the center. Very striking dahlia.

$\$ 1.00$

BARBARA REDFERN. 6ft. Redfern. A very large, choice flower on long, erect stems. Color a beautiful blending or oldrose and old-gold.

$\$ 2.00$

BEN WILSON. $4 \mathrm{ft}$.

Murphy.

Large and fine. Color orange red, very lightly tipped yellow. Good stems........50

BESTYET, R

$6 \mathrm{ft}$.

Redding.

A large attractive flower. Color clear red, reverse yellow. Petals so arranged that the flowers look about half red and half yellow. Stems rather pendant.

$75 \mathrm{c}$

BIG BERTHA, R. 5ft. Redding An immense new decorative of clear canary vellow color. A wonderful flower that is listed for the first time.

$\$ 5.00$

BIG BROTHER, R. 4ft. Redding. A massive flower, very broad and deep. A good stem, blooms freely and every one is of exhibition size. Color a lovely blending of old-rose and old-gold.

$\$ 5.00$

BIG BOY.

$4 \mathrm{ft}$.

Redding.

A great big fellow that every one likes. Color a fine deep red. A good bloomer on good stenis.

$\$ 1.00$

BENGAL TIGER. 5ft. Redding. A large regular formed flower on good stems. Color deep Jellow-buff, heavily splashed, and striped crimson.
BILTMORE.

$6 \mathrm{ft}$.

Stillman

Excellent garden dahlia, its contrasting colors making a striking display. The stems are pendant.

$\$ 1.00$

BOY SCOUT, R.

$4 \mathrm{ft}$.

Redding.

A fine flower on good stems, excellent for cutting. Color deep pink.

$50 \mathrm{c}$

BOLD BEAUTY, R.

$4 \mathrm{ft}$.

Redding.

An enormous flower on long rigid stems. Color: purple attractively shaded lighter.

Plants of medium growth, but wonderful bloomers. One of the best.

$\$ 2.00$

BONNIE BRAE. $4 \frac{1}{2} \mathrm{ft}$. Broomall. Color cream, shaded blush pink. A beautiful dahlia of immense size. A free bloomer of all exhibition flowers. Excellent long stems for cutting.

$75 \mathrm{c}$

BREEZE LAWN.

$4 \mathrm{ft}$.

Dreer.

Color brilliant, firey scarlet. Always a mass of blooms. Blooms erect but the stems are short. Garden variety.

$50 \mathrm{c}$

BULL MOOSE $3 \frac{1}{2} \mathrm{ft}$ F. F. \& R. Color a crushed strawberry shade, a color that is always admired. Large fine flower on erect stems. Very free flowering and one of the first to bloom

$50 \mathrm{c}$

BUNKER HILL. R. $5 \frac{1}{1 / 2} \mathrm{ft}$. Redding. A striking new dahlia of good size and form. Color deep yellow, heavily striped and speckled with maroon. Blooms held well up on good stems.

$\$ 2.00$

BUTTER SCOTCH, R. 4ft. Redding. A distinct new variety, both in color and formation. Large and free flowering, held erect on straight stems. Color a pleasing creany-buff shade.

$\$ 2.00$

\section{CALIFORNIA SUPERBA. $4 \frac{1}{2} \mathrm{ft}$.}

Bessie Boston. A very fine flower of large size. Color pink shaded to white.

$50 \mathrm{c}$

CARMENCITA 31/2ft. Bessie Boston. A lovely varigated decorative. Color yellow with just enough crimson markings to give it a pleasing effect.

$\$ 1.00$

CAPE COD, R.

$5 \mathrm{ft}$.

Redding. An ideal flower, large size, finely formed, and a good bloomer on good stems. Color $\tan$ shaded deeper.

$\$ 1.00$ 
CASPER G. WARE 31/2ft. Dahliadel. An immense flower of perfect form and pleasing color. Plants are quite dwarf. Color silvery violet-rose.

$\$ 1.00$

CATHERINE WILCOX. 5ft. Marean. A flower of good form and attractive color. White with the tips of petals tipped with bright cerise.

$75 \mathrm{c}$

CHAMPAGNE 6ft. Bessie Boston. Color golden champagne shading to chamois A model flower in every way, its size, form, color, stem and habit of growth being all that could be desired

$\$ 1.00$

CHARM. $5 \mathrm{ft}$.

Marean. Color a striking combination of deep burntorange and yellow. Attracts a lot of attention in the gardens.

$75 \mathrm{c}$

CHAS. STRATTON.

6ft. Stratton.

A massive flower on strong, upright stems. One of the largest. Color pale gold, suffused rose. Very fine

$\$ 1.00$

CHIC, R. $5 \mathrm{ft}$ Redding. Large beautiful new hybrid that is greatly admired every season. Color bright, deep rose. Quite distinct.

$\$ 2.00$

CHOCOLATE SOLDIER 51/2ft. Doolittle. Color chocolate maroon. A very good fiower on good stems.

$35 \mathrm{c}$

CITY OF LAWRENCE. 6ft. Reed. An immense flower of very attractive formation. Color clear, deep yellow. One of the largest and finest yellows.

$\$ 1.00$

CITY OF TRENTON. 6ft. Dahliadel. A fine variety of immense size on strong upright stems. Color tangerine, with strawberry red reverse.

$\$ 2.00$

CLAIRE KULP. $4 \mathrm{ft}$.

Peacock. Color cardinal-red, shaded to yellow at the base of petals. Large.

$25 \mathrm{c}$

COLUMBIA. $5 \mathrm{ft}$.

Redding. A giant flower of distinct but attractive coloring, a deep bronzy red shade that is difficult to describe.

$\$ 1.00$

CRINKLES. R.

$4 \mathrm{ft}$.

Redding.

Color shades of amber with suffusions of old rose, the reverse crimson. A fine new variety with the edge of the petals beautifully crinkled.

$\$ 2.00$

DANGER, R.

$5 \mathrm{ft}$.

Redding.

A good, big red dahlia that is very satisfactory. Free flowering.
DEE-LIGHTED.

$5 \mathrm{ft}$. Childs.

This variety always attracts attention. The dahlia with the "Roosevelt" smile as it is caricatured, formation at center suggesting its name. Color pure white.

$35 \mathrm{c}$

D. M. MOORE.

$3 \mathrm{ft}$.

Wilmore. About the darkest dahlia, color a very dark maroon, almost black. Large.

$35 \mathrm{c}$

DR. TEVIS.

$6 \mathrm{ft}$.

Pelicano.

Color salmon-rose, suffused old rose and apricot. A huge flower, that blooms freely on upright stems.

$75 \mathrm{c}$

\section{EAGLE ROCK BEAUTY. 5ft.}

Broomall. A fine impressive dahlia. Color pastel pink shading to creamy white at the center. An immense, wonderful flower on excellent stems. One of the finest. .................... $\$ 3.00$

ELIZABETH (LIZZIE) FORD, R. $5 \frac{1}{2} \mathrm{ft}$. Redding.

Each year this dahlia proves to be one of the greatest attractions in my gardens. Its enormous size, beautiful color and extreme long stems appeals to every one. Blooms freely and every bloom a perfect giant. Color rosy red.

$\$ 2.00$

ELIZA CLARK BULL. 4ft. Bessie Boston. The largest and best pure white decorative. A perfectly double flower that is held erect on straight stems.

$\$ 2.00$

ELIZABETH SLOCUMBE. 4\%1/2ft. Slocumbe. Color a rich fuchsia-garnet that attracts the attention at once. Large finely formed flower on good stems.

ELITE GLORI. $5 \frac{1}{2} \mathrm{ft}$. Kennedy. A monster decorative on rigid, cane-like stems. Color a rich glowing red. A great prize winner at the exhibitions. ...... $\$ .100$

ELLINOR VANDERVEER. 51/2ft. Seal. An incomparable dahlia. A magnificent rose-pink that is greatly admired. Blooms of giant size are borne in great profusion on perfect stems.

$\$ 1.00$

E. T. BEDFORD. $5 \frac{1}{2} \mathrm{ft}$ Mareall. Color purple with lighter shadings. Large fine variety.

$75 \mathrm{c}$

EVA COLE.

$5 \mathrm{ft}$.

Murphy.

An unusual large splendid flower. Grows erect on good stems. Color an attractive red and yellow combination.
$\$ 3.00$ 

FAIRYLAND, R.
A distinct new variety. Color yellow tipped white. An unusual flower. ................ $\$ 5.00$

FAN TAN.

$4 \mathrm{ft}$.

Redding. Color wine, heavily tipped white. A very popular dahlia, attracting a lot of attention. Excellent for cutting, a medium size flower on erect stems.

$\$ 1.00$

FIFTY FIFTY.

4ft. Redding. Color red and white in about equal proportions, varying in each flower. Fine cutting variety, blooms freely on good stems. .. 50c

\section{FIREBUSH, R.}

$4 \frac{1}{2} \mathrm{ft}$.

Redding.

Well named as the plants are a solid mass of bright red blooms the entire season. Fine for garden or cutting.

$\$ 1.00$

FIREFLY, R.

$6 \mathrm{ft}$.

Redding. Color deep crimson tipped white. Large and attractive.

$\$ 1.00$

FIRST LADY, R.

4ft. Redding.

This is a splendid new giant decorative.

Color light pink throughout. An immense true decorative. Blooms erect.

$\$ 10.00$

FLASHLIGHT.

$5 \mathrm{ft}$.

Redding.

A large new decorative of very attractive color and form. Color deep orange shading to orange-russet.

$\$ 1.50$

FOURTH OF JULY. 4ft. Redding. A very striking new decorative. Color yellow, thickly speckled crimson. Many of the blooms are white tipped.

$\$ 2.00$

\section{FORT WASHINGTON. $5 \frac{1}{1 / 2} \mathrm{ft}$.}

Reindfleisch. Color dark mahogany-red. A grand flower on perfectly erect stems.

$\$ 2.00$

\section{FRANK HUMPHRIES.}

$3 \mathrm{ft}$.

Titus. Color light yellow, splashed and striped with crimson. A huge flower with deep full centers but pendant stems.

$\$ 1.00$

GIANTESS.

$$
5 \frac{1}{2} \mathrm{ft} \text {. }
$$

Marean. A giant flower, erect on stout stems. Color shades of amber.

$75 \mathrm{c}$

\section{GLORIEUX.}

$5^{1 / 2} \mathrm{ft}$.

Mastic.

Color yellow deepening to bronze, often tipped white. Large and fine.

$50 \mathrm{c}$

GOLD ORE, R.

$5 \mathrm{ft}$.

Redding.

Color old gold with just a light suffusion of red at times. A giant flower with broad flat petals. Free flowering on long stems. A splendid dahlia.
GOLD BOND, R.

$4 \mathrm{ft}$.

Redding.

Color golden yellow without shading. Large fine flower on good stems.

$75 \mathrm{c}$

GOLDEN WEDDING, R. $5 \mathrm{ft}$. Redding. Color clear canary yellow. An immense flower, full deep centered and on good stems. One of the best.

$\$ 1.50$

GRANDFATHER, R. 4ft. Redding. A new giant red decorative on a very long, bare stem that holds bloom very erect. One of the best reds.

$\$ 2.50$

GRANDMOTHER, R. 5ft. Redding. A flower of exquisite beauty, wonderful size and form. Blooms very freely on a good stem. Every bloom large and fine. Color lavender-pink, shading to a creamy-pink at the center. A beauty.

$\$ 2.00$

GRETNA GREEN, R. 4ft. Redding. A model flower, erect on straight stems. Color a very attractive shade of light purple. Greatly admired.

HARRY MAYER.

$5 \mathrm{ft}$.

Saltsam.

Color silvery pink with a rose-pink reverse, very beautiful. An immense flower of perfect form. A grand dahlia.

$\$ 1.00$

HARRY SHELDON, JR. 31/2ft. Murphy. An immense exhibition flower. Color pink, shading to white at center. A fine flower but the stems are pendant.

$50 \mathrm{c}$

JANE COWL.

$5 \frac{1}{2} \mathrm{ft}$.

Downs.

An incomparable dahlia. A beautiful flower, as large as any grown, free flowering and held perfectly erect on long straight stems. Color warm buff and old gold, blended to a deeper shade towards the center. One of the finest dahlias.

$\$ 5.00$

JANE SELBY. 6ft. Bessie Boston. Color mauve-pink. A fine large flower on erect stems.

$50 \mathrm{c}$

JACK ROSE.

$3 \mathrm{ft}$.

Peacock. Color brilliant crimson. A fine cutting variety, stems straight.

$15 \mathrm{c}$

JERSEY'S BEAUTY. $6 \mathrm{ft}$ Waite. A leading prize winner, wonderful for exhibition or for cutting. Its large flowers are borne perfectly erect on long, cane-like stems. Color true pink.

$\$ 1.00$

JERSEY'S BEACON.

$31,2 \mathrm{ft}$. Waite. An exhibition flower of the largest size. Color chinese scarlet with lighter reverse, giving it a two toned effect. Every one stops to admire this dahlia. 
JERSEY'S JEWELL. 4ft. Waite. Color mallow-pink, a beautiful shade. A model flower on fine stems.

$\$ 1.00$

JERSEI'S MOMMOTH. $5^{1} \mathrm{ft}_{2}$ Waite. Color golden mahogany or burnt orange. The largest decorative of this color. .. \$1.00

JERSEY'S SOVERIGN. 3ft. Waite. A free flowering dwarf variety of distinct color. Orange salmon.

$50 \mathrm{c}$

JOHN LEIVIS CHILDS. $5 \mathrm{ft}$. Bessie Boston. A stunning flower of large size and distinct color; chrome yellow, suffused, stripped and splashed scarlet, often tipped white. Produces many different combinations on a single plant.

$\$ 1.00$

JUNIOR.

$3^{1 / 2 \mathrm{ft}}$.

Seal.

A sensational flower of deep lavender color. A perfect monster, winning many prizes as the largest flower.

$75 \mathrm{c}$

JUDGE MAREAN. 4ft. Marean. A riot of blended colors, yellow, gold, orange and salmon beautifully blended. A wonderful free flowering dahlia on excellent stems. A model dahlia

$\$ 1.00$

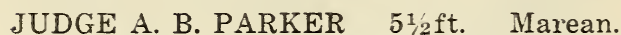
Large deep, full centered flower, never shows open center. Color golden-buff. .... 50c

KEMAL PASHA, R. $31 / 2 \mathrm{ft}$. Redding. Color bright scarlet, distinctly tipped white. Nicely formed flowers of medium size, erect on perfectly straight stems. An excellent variety for cutting.

$\$ 1.00$

KING ALBERT. 5ft. Ballego Color royal purple, shaded violet on the outer petals. A large graceful flower, erect on cane-like stems.

$\$ 1.00$

KITTY DUNLAP. 5ft. Bessie Boston. Agrand good dahlia erect on straight stems. Color a delightful shade of the Am. Beauty rose. Ver'y popular.

$75 c$

LADY GAY. $51 / 2 \mathrm{ft}$.

Redding. A peaony-decorative that is always admired. Color orange with white tips. Blooms well up on straight stems.

$75 \mathrm{c}$

LATENDER GEM. 51/2ft. Redding. Hybrid decorative of distinct form. Color light lavender shading to deep lavender on the edge of the petals.
LE GRAND MANITOU. 3ft. Charmet. A very popular dahlia, its giant size and striking color combination catching the eye at once. Color pinkish white ground striped and splashed reddish violet.

$35 \mathrm{c}$

LEMON DROP, R. $\quad 3 \frac{1}{2} \mathrm{ft} \quad$ Redding. A giant decorative of model form. Color soft lemon yellow. Early and free flowering c.n good stems.

$\$ 2.00$

LIBERTY BOND.

$4 \mathrm{ft}$.

Broomall

Color a warm blending of salmon-bronze and buff. Large hybrid decorative of graceful form. Blooms erect.

MADONNA MIA. $31 / 2 \mathrm{ft}$. Redding. Color crimson, heavily tipped white. One of the finest of the red and white dahlias. Large and free flowering.

$\$ 2.50$

MAH JONG, R. $3 \mathrm{ft}$. Redding. A striking novelty that is different. Color oriental red and yellow very attractive blending. Produces perfectly double flowers in great profussion the entire season. Every bloom face up.

$\$ 1.00$

MAID OF THE MIST. 5ft. Slocumbe. Color a lovely deep cream, shading to salmon-pink on the outer petals, that roll back making a very deep as well as broad flower. Very beautiful.

$\$ 1.50$

MAID OF PLYMOUTH. 4ft Redding. A charming dahlia of distinct color, yellow at the base of the petals, changing to bronze along the outer edges, and distinctly tipped white. Distinct beautiful foliage, unlike any other dahlia.

$\$ 2.50$

MARGARET MASSON. $5 \mathrm{ft}$.

Fisher \& Mason. A wonderful exhibition dahlia of immense size. Color a beautiful silvery rose-pink. One of the best.

$\$ 1.00$

\section{MARGARET WOODROW WILSON. $3 \mathrm{ft}$.} Fisher \& Mason.

One of the best and largest, keeping its immense size the whole season although blooming profusely. Color opalescent-pink, the reverse phlox-pink.

$\$ 1.00$

MARION WHEELER. $31 \frac{1}{2} \mathrm{ft}$. Stillman. Color beautiful soft pink. A large fine dahlia of true form.

$50 \mathrm{c}$

MARMION. $31 / 2 \mathrm{ft}$ Mastic. A beautiful flower of enormous size and wonderful formation. Color golden-yellow with bronze suffusions. 
MERIT.

$5 \mathrm{ft}$.

Redding. Color bittersweet-pink, shaded amber and tipped white. Free flowering. $50 c$

MERITORIOUS. $51 / 2 \mathrm{ft}$.

Bennett. Color orange-salmon and yellow, suffused yellow and tipped white. Large distinct variety. Stems pendant.

$75 c$

MEPHISTOPHELES. $6 \mathrm{ft}$. Marean. Color ruby red, the points of the petals lightly tipped yellow. Its large flowers are borne erect on long stems.

$50 \mathrm{c}$

MIDNIGHT SUN, R. $\quad 41 \frac{1}{2} \mathrm{ft}$. Redding. A distinct new novelty of immense size. Color a gorgeous blending of yellow, gold amber and scarlet. Stout stems hold the giant flowers face up.

$\$ 5.00$

MILLIONAIRE,

$31 / 2 \mathrm{ft}$.

Stillman. A real wonder that is always in demand. One of the largest grown. Color a lovely clear mauve.

$75 \mathrm{c}$

MINUET. $R$.

$3 \mathrm{ft}$.

Redding.

A beautiful new variety of exquisite color, cream suffused peach and rose shades. An unusual large graceful flower.

$\$ 5.00$

MISS CAPE COD, R. 4ft. Redding. An outstanding novelty even when grown among the largest and finest dahlias. The color is rosaline purple with lighter shadings, a color rather difficult to describe. Every bloom a perfect giant. One must see this beauty to appreciate its great size, wonderful form and beautiful color. $\quad \$ 10.00$

MISS COLUMBIA, R. 5ft. Redding. A giant flower on upright stems. Color deep salmon-bronze. Extra good.

$\$ 1.00$

MISS NEW ENGLAND, R. 5ft. Redding. A giant flower of the hybrid decorative type. Color a lovely blending of amber and gold. Very graceful flower.

$\$ 5.00$

MISS PLYMOUTH, R. $3 \frac{1}{2} \mathrm{ft}$. Redding. An unusual attractive novelty. The ground color is fawn-pink, suffused with ashes of roses towards the center, each petal daintly tipped white. Flowers of large size deep centered. Stems excellent.

$\$ 5.00$

MORDELLA.

$6 \mathrm{ft}$.

Kemp.

A large fine flower on excellent stems for cutting. Color bright apricot-buff. One of the finest.
MR. CROWLEY.

$3 \mathrm{ft}$.

Broomall.

Color rich glowing amber-pink shading to yellow. A wonderful garden dahlia, but the stems are rather short.

$75 \mathrm{c}$

MRS. A. J. SELLERS. 4ft. Sellers. Color creamy salmon shading to flesh-pink. Large flower on straight stems. A very beautiful dahlia.

$\$ 1.00$

MRS. CARL SALBACH. 51/2ft. Salbach. A model dahlia, erect on long straight stems. Color marsh-mallow-pink, shaded lighter. Fine for cutting.

MRS. CHAS. W. REDDING, R. $3 \mathrm{ft}$.

Redding. This new giant decorative must be seen to be appreciated. Color gold with lighter shadings, suffused and tipped rose-carmin. A beautiful blending of colors. .......... $\$ 3.00$

MRS. CHAS. CHASE. $3 \mathrm{ft}$. Seal. Color clear pink. An immense flower with long narrow petals.

$75 c$

MRS. ELEANOR MARTIN. $\quad 4 \frac{1}{2} 2 \mathrm{ft}$.

Pelicano.

One of the very finest dahlias ever introduced. The color is well described as mulberry, suffused with gold. A beautiful color that is different from any other dahlia. A perfect giant with long stiff stems that hold it erect. Free flowering.

$\$ 1.00$

MRS. ESTELLE L. LINDSEY. $\quad 31 / 2 \mathrm{ft}$.

Broomall.

Colors scarlet and gold, the colors of the well known dahlia "Geisha" produced in a monster decorative. One of the largest. Upright on straight stems.

$75 \mathrm{c}$

MRS. HARRY WRIGHT. 5ft. Alexander. Color golden apricot-buff. A huge flower of pleasing formation.

$\$ 1.00$

MRS. I. D. VER WARNER $51 / 2 \mathrm{ft}$.

Marean One of the most popular dahlias. A model flower of giant size on long cane-like stems. Color a beautiful deep mauve-pink, or orchid. Well worth growing.

$\$ 1.00$

MRS. JOHN SHEEPERS. 5ft. Marean. A grand good flower of recent introduction. Color canary yellow with a beautiful pink suffusion. A perfect monster flower on stout stems. Always admired.

$\$ 1.00$

MRS. J. A. BABBITT.

$5 \mathrm{ft}$.

Root. Color deep yellow, reverse of petals overlaid crimson. Flower of immense size, the petals long and narrow. 
MRS. MILDRED MEADER. 4ft. Redding. Unique and striking. Color wine-crimson, tipped white. Varies greatly.

$50 \mathrm{c}$

MRS. T. B. ACKERSON. 3ft. Childs. A charming flower that always makes an attractive display in the garden. One of the freest bloomers. Color carmine flushed yellow, tipped and shaded pearl.

$50 \mathrm{c}$

NOTHERN LIGHTS, R. 4ft. Redding. Color red and gold combination that always attracts attention. A large true decorative with full double center.

$\$ 1.00$

$\mathrm{OH}$ HENRY, R. 4ft. Redding.

A gorgeous new decorative that is in great

demand. One of the most striking varigated dahlias grown. Color gold heavily splashed with deep red.

$\$ 5.00$

OUR COUNTRY.

$4 \mathrm{ft}$.

Stillman.

A monster flower of massive proportions. Color deep purple, tipped white which never fails. Its striking color and wonderful size make it worth growing although the stems are pendant.

$\$ 1.50$

OREGON BEAUTY. $3 \mathrm{ft}$.

Gill.

Large fine flower resembling a giant paeony. Color oriental red suffused carmine. Fine garden variety.

$35 \mathrm{c}$

PATRICK O'MARA. $51 \frac{1}{2} \mathrm{ft}$. Vincent. Large fine flower on straight stems. Color orange-buff, lightly tinged rose. Fine for cutting.

PAUL MICHAEL. 3ft. Michael. One of the most beautiful dahlias. a griant flower of wonderful color and form. Color glistening gold with bronze shadings. Free bloomer, every flower perfect.

$\$ 1.00$

PAUL REVERE. $3 \frac{1}{2} \mathrm{ft}$. Bissel. Color a dazzling bright red. An immense deep, full flower.

$\$ 2.50$

PEAC,IES.

$31 / 2$ fit.

Redding.

Color an unusual attractive blending of peach, salmon anc. apricot shades. A large full double flower of quite regular formation. Free flowering.

$75 \mathrm{c}$

PILGRIM MAIDEN, R. 41/2ft. Redding. Color rosy-lavender. A lovely flower that grows more popular each year.

$50 \mathrm{c}$

PIN WHEEL.

$51 / 2 \mathrm{ft}$.

Redding.

Paeony-decorative. Color crimson, tipped white. Tall upright habit.
PLYMOUTH, R.

$5 \mathrm{ft}$.

Redding.

Color a beautiful clear pink that is very desirable. Large and fine.

$\$ 1.00$

PLYMOUTH GLORY, R. 4 $\frac{1}{2} \mathrm{ft}$. Redding. A distinct beautiful flower, both in form and color. Deep orange, the points of the petals tipped white.

$\$ 2.50$

PLYMOUTH QUEEN, R. 4ft. Redding. Color cream shading to a clear primrose at the center. Large and fine.

$\$ 1.00$

PLYMOUTH ROCK, R. 41/2ft. Redding. Color delicate pink shading off to a pure white center. A very large flower of distinct formation.

$\$ 1.00$

PLYMOUTH STAR, R. $3 \frac{1}{2} \mathrm{ft}$. Redding. Color a real live rose-red. Star-shaped flower on erect stems.

$75 \mathrm{c}$

PLYMOUTH WONDER, R. 4ft. Redding. Color yellow shading to amber and again to pure white tips. A beautiful flower in every respect.

$\$ 2.50$

POLAR SNOW.

$41 / 2 \mathrm{ft}$.

Marean.

One of the best of the pure white decoratives. A giant flower with perfectly double centers. I have never seen an open center although a very free bloomer.

$\$ 1.00$

PRESIDENT WILSON. 3ft. Jones. A sensational dahlia that is always over sold. One of the greatest attractions in the gardens. A giant flower that is always perfectly double. Color brilliant vermillion, distinctly tipped white.

$\$ 2.50$

PRIDE OF CALIFORNIA. 51/2ft. Burns. A huge flower, perfect in every way. Color deep crimson.

$50 \mathrm{c}$

PRIDE OF PLYMOUTH, R. 4ft. Redding. Color yellow-buff, shaded to gold at the center. Large and fine.

$50 \mathrm{c}$

PRIDE OF STRAFFORD. 51/2ft. Meachen. A wonderful giant flower, one of the best. Color orange shading to orange-yellow at the base. Petals slightly quilled.

$\$ 3.00$

PRIMROSE LADY, R. $3 \frac{1}{2} \mathrm{ft}$. Redding. An enormous flower of perfect form. Color deep primrose yellow.

$\$ 1.00$

PRIMULA REX. $31 \frac{1}{2} \mathrm{ft}$. Broomall. A real gem. This immense new dahlia ranks with the finest. Color light primrose or deep cream. Good stems. 
PRINCESS MARY. 3ft. Hornsveld. Color vivid pink. Upright on good stems, fine for cutting. $35 \mathrm{c}$ PRINCESS PAT. $5 \mathrm{ft}$. McWhirter. Large fine variety on a long cane-like stem. Color old rose. Very desirable. $50 \mathrm{c}$ PURE GOLD, R. $31 / 2 \mathrm{ft}$. Redding. Color pure gold. Very desirable for cutting. Good stems, keeps well. $75 \mathrm{c}$ PURPLE MANITOU. 3ft. Rivorie. Color deep rich purple. A large perfect decorative, upright on straight stems. A very popular dahlia.

$35 \mathrm{c}$

\section{QUEEN OF THE GARDEN BEAUTIFUL.} $5 \mathrm{ft}$.

Burnes. One of the largest and one of the best. Color soft primrose-yellow. Blooms freely, face up on rigid stems.

$\$ 2.50$

\section{RADIO.}

$41 / 2 \mathrm{ft}$.

Sampson.

A very striking variety, about the best of its color. Blood-red and yellow, distributed in an attractive manner. A giant flower that blooms erect on strong stems. .... $\$ 1.50$

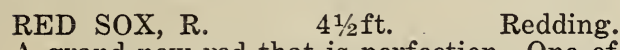
A grand new red that is perfection. One of the largest grown. Blooms erect on long bare, perfectly straight stems. Color, bright crimson-red. Form approaches the hybrid cactus type. A real gem.

$\$ 2.00$

RIPPLES. $3 \mathrm{ft}$.

Redding. A new giant decorative of wonderful formation, its petals are beautifully rippled. Color wine crimson.

$\$ 5.00$

RIP VAN WINKLE, R. $5 \frac{1}{2} \mathrm{ft}$. Redding. A huge, massive, flower, very deep full centered. Color a beautiful golden-bronze, the whole flower covered with a glistening golden sheen.

$\$ 1.00$

ROBERT TREAT. 51/2ft. Mueller. An outstanding variety of the most pleasing Am. Beauty color. It produces its immense flowers in great profusion on straight stems well above the foliage. $\$ 1.00$

ROBERT SCOTT.

$5 \mathrm{ft}$.

Bedford.

A grand good dahlia. Blooms of giant size are freely produced on good stems. Color a bright apricot yellow with rose shadings. Always greatly admired. $\$ 1.00$

ROSA NELL. $4 \frac{1}{2} \mathrm{ft}$. Broomall. Color clear bright rose. A giant flower of fine form, petals notched. Blooms erect on straight stems. Very popular.
ROSE FALLON

$4 \mathrm{ft}$.

A large fine flower of distinct color, a deep golden-russet. Upright on straight stems. Excellent for cutting.

$\$ 1.00$

SAGAMORE.

$5 \mathrm{ft}$.

Badetty.

Color amber-gold, deepening at the center. Large and fine on good stems.

$\$ 1.00$

SAMPSON. $\quad 5 \mathrm{ft} . \quad$ Babylon. Color yellow, tipped and shaded red in a beautiful manner. A very large flower of regular formation. Excellent for cutting, free bloomer, good stems.

$\$ 1.00$

\section{SANHICAN'S BLUEBIRD. $4 \mathrm{ft}$.}

Fisher \& Mason. •

Color violet blue on the outer petals, shading to violet at the center, the nearest blue dahlia. A noble flower on wiry stems. Distinct novelty.

$\$ 1.00$

\section{SANHICAN'S MAGNET. 3ft.}

Fisher \& Mason. A distinct novelty of enormous size. The blooms are produced freely, face up on stout stems. Color pale amaranth pink tinted deep amaranth pink, reverse of petals heavily veined claret.

$\$ 1.00$

SAN MATEO. 6ft. Bessie Boston. A monster bi-colored dahlia. Color deep yellow, heavily striped and splashed scarlet. Very showy variety, attracting a great deal of attention.

$\$ 1.00$

SHANNON. $51 / 2 \mathrm{ft}$. Cayeux. Color yellow-buff and scarlet well blended. A large attractive flower. ………….... $50 \mathrm{c}$

SHOWER OF GOLD. 4ft. Redding. A new hybrid decorative of beautiful form and color. Blooms very large with petals beautifully waved. Color clear rich gold with-out shading.

$\$ 5.00$

\section{SHUDOW'S LAVENDER. $6 \mathrm{ft}$.}

Bessie Boston. Color silvery-lavender with white shadings. A wonderful large flower that never shows an open center. Blooms upright on a long cane-like stem.

$\$ 1.00$

SILVER MOON, R. 3ft. Redding. Color primrose, shading to white at the tips. A beautiful new hybrid of wonderful formation.

$\$ 10.00$

SKYROCKET, R. $\quad 5 \mathrm{ft}$. Redding. Color clear bright red. A giant flower of true decorative form. $50 \mathrm{c}$ 
SNOWDRIFT.

$3 \mathrm{ft}$.

Broomall.

A fine large, double white that is very popular. Blooms erect but requires disbuding for long stems.

$\$ 1.00$

S. O. S.

$5 \mathrm{ft}$.

Marshall.

An exhibition dahlia of wonderful size and form. A perfect giant flower but the stems are pendant. Color deep red.

$\$ 1.00$

SOUVENIR DOAZON. $6 \mathrm{ft}$ Bruant. Color orange-red. A good old timer, blooms freely and erect on long stems.

$25 c$

ST. FRANCIS. 4ft. Bessie Boston. Color soft cream, brightened with a pinkish glow on the outer petals. Blooms face up on strong stems.

$50 \mathrm{c}$

SUMMERTIME, R. $5 \mathrm{ft}$. Redding. Color soft butter yellow. A fine large flower of even form, good bloomer on very good stems.

$\$ 1.00$

SUPER SIX, R.

$6 \mathrm{ft}$.

Redding.

An immense new decorative that is a real giant. Stands perfectly erect on a long bare stem. Color pure canary-yellow. One of the greatest attractions in the fields every season.

$\$ 5.00$

TAPS, R

$51 / 2 \mathrm{ft}$.

Redding.

Color deep crimson, tipped pure white to about one half of the petals. A very striking variety that is always admired.

$\$ 1.00$

TEDDY BEAR, R. $51 / 2 \mathrm{ft}$. Redding. An enormous flower of great merit. Color a rich bronze orange with a golden sheen. Erect on good stems.

$\$ 2.00$

TENOR ALVAREZ. 51/2ft. Nonin. Hybrid decorative of unusual color, violetred ground, thickly speckled velvety brown. Large graceful flower, quite erect on long stems.

$75 \mathrm{c}$

THE BASHFUL GIANT. 31/2ft. Marean. A well named variety, the blooms are so massive that they are somewhat pendant although having a good stout stem. Color apricot with golden suffusions. A very popular dahlia. $\$ 1.00$

THE CHARMER, R. 5ft. Redding. Color lemon yellow shading off to creamy white at the tips. Good.
THE CO-ED, R.

$41 / 2 \mathrm{ft}$.

Redding.

The exquisite beauty of this wonderful new dahlia must be seen to be appreciated. The color is best described as silvery rose-pink with cream suffusions, the extreme end of each petal tipped with gold. An immense flower, deep and full centered, petals slightly rolled back. Borme quite erect on good long stems.

$\$ 10.00$

THE FLAPPER, R. 4ft. Redding. Color yellow, flushed scarlet in a very pleasing manner. Blooms good size, of true form and on good stems.

$\$ 1.00$

THE GRIZZLY.

$6 \mathrm{ft}$.

Burns.

One of the finest and one of the most popular dahlias. A giant flower that is borne high up on long stems. Color dark, velvety crimson-maroon.

$\$ 1.00$

THE NATIVE, R. $\quad 5 \mathrm{ft}$ Redding. A giant flower that blooms very freely and retains its large size the whole season. Color an attractive combination of strawyellow and scarlet. Every one likes this dahlia and it is well worth growing. .. $\$ 1.00$

THE EIGHTH WONDER, R. $3 \frac{1}{2} \mathrm{ft}$.

Redding.

New giant hybrid decorative of wonderful formation, petals very broad and loosely arranged. Color butter-yellow, suffused apricot. A very good bloomer of large flowers the whole season.

$\$ 5.00$

THE GOLD DIGGER, R. 4ft Redding. New hybrid decorative. An artistic flower with beautifully twisted petals. Color pure gold. A beauty.

$\$ 5.00$

THE NORGE, R. $31 / 2 \mathrm{ft}$. Redding. A new pure white decorative that is very fine. A consistant bloomer.

$\$ 1.00$

THE TELEGRAM. 51/2ft. Marshall. An unusual attractive dahlia of large size Color orange yellow, distinctly tipped pure white. Very attractive.

$\$ 2.50$

THE SPHINX, R. $\quad 5 \mathrm{ft}$. Redding. Color an unusual red and yellow combination that attracts the immediate attention. Large size and good stems. $\$ 3.00$

THE YANKEE, R. $5 \mathrm{ft}$. Redding. Color yellow shading to deep amber towards the tips. A giant hybrid. 
TISH, R.

$3 \mathrm{ft}$.

Redding.

Color salmon to shrimp-pink, suffused with gold. A giant flower that blooms erect but rather short stems.

$\$ 2.50$

TIGER LILY, R.

$5 \mathrm{ft}$.

Redding.

A beautiful fancy decorative. Color straw, suffused pink and yellow, attractively pencilled with crimson. Large and distinct. Only a few roots for sale.

$\$ 5.00$

TOMMY ATKINS. 3ft. Bessie Boston. Color flaming scarlet without shading. A fine flower on good stem.

$50 \mathrm{c}$

TOM MIX.

$5 \mathrm{ft}$.

Distinct new fancy decorative of unique color, red, yellow and white attractively arranged. Large and full centered.

$\$ 1.00$

TRENTONIAN. $4 \frac{1}{2} \mathrm{ft}$. Fisher \& Mason. A model flower of large size on the best of stems. Color a blending of old-gold, amber and bronze.

$\$ 1.00$

TRUE AMERICAN, R. 5ft. Redding. Color royal purple, heavily tipped white, varies somewhat. A giant flower that is held quite erect on long stems.

$\$ 2.00$

VENUS.

$4 \mathrm{ft}$.

Marean.

A lovely flower that every one should grow. large perfect flower on excellent stems. One of the best for cutting. Color creamywhite, with deep lavender suffusions. .... $75 \mathrm{c}$

VERNA THOMPSON. 4ft. Stillman. Color white, heavily clouded cerise. Paeony decorative, many blooms showing open centers. Very free flowering.

$35 \mathrm{c}$

VIOLET, R. $3 \mathrm{ft}$.

Redding. An excellent variety for cutting. Flowers of medium size on long straight stems. Color light to deep violet.

$35 \mathrm{c}$

WARREN'S JUMBO.

3ft. Warren. A truly grand flower, a perfect giant of wonderful formation. Color a real lively golden-bronze that appeals to all.
WEST POINT, R.

$41 / 2 \mathrm{ft}$.

Redding.

A grand good red decorative, large perfect flowers on good stems. Very free flowering. Fine for garden display or for cutting. Color crimson-red.

$75 \mathrm{c}$

WHOOPEE, R.

$3 \mathrm{ft}$.

Redding. A seedling of Jersey's Beacon. Color a shade lighter with a creamy reverse. An immense double flower with very broad, loosely arranged petals. A beauty.

$\$ 10.00$

WINFIELD SLOCUMBE. $3 \mathrm{ft}$. Slocumbe. An irrisistible dahlia. Color a beautiful golden orange shaded to burnt orange at the center. A model flower, perfect in form and a consistant bloomer.

$\$ 1.00$

WIZARD OF OZ.

$4 \mathrm{ft}$.

Doolittle. A remarkable dahlia. This giant hybrid decorative is one of the most beautiful dahlias, often produces several giant flowers on a single stem. Color glowing amber-pink or pastel pink.

$\$ 1.50$

WORLD'S CHAMPION, R. 3ft Redding. This new novelty is attracting a great deal of attention. Greatly admired for its huge, massive formation and distinct color. The color is a crimson-purple shade with a pure white collarette petal showing up through the center of each broad petal. A very unusual but beautiful flower.

$\$ 10.00$

WORLD'S WONDER. 41/2 ft. Stillman. Color a beautiful shade of golden-salmon. Large perfectly double centered flower on good stems. Excellent garden dahlia or for cutting puposes.

$\$ 1.00$

YELLOW JACKET. 3ft. Redding. An extra early, free blooming variety on good stems for cutting. Color clear sulphur yellow. Very satisfactory.

$50 \mathrm{c}$

YOUNG AMERICA, R. 31/2ft. Redding. Color clear canary yellow with-out shading. An exhibition variety of immense size. Stems good, form distinct. 
A. C. LAWRENCE. 51/2ft. Hathaway. Color a beautiful shade of flesh pink. One of the finest in this class, very large and of perfect form.

ALARM. $\quad 3 f t . \quad$ Redding. This immense new, deep red hybrid castus is of the highest order, a very graceful flower of great depth.

$\$ 3.00$

ALICE WHITTIER.

$51 / 2 \mathrm{ft}$.

Reed. One of the finest of its color and type. Its immense flowers are produced freely on long straight stems. Its form is nearly that of the true cactus, the petals long and narrow. Color clear primrose yellow. $\$ 1.50$

AMERICAN EAGLE, R. 4ft. Redding. Color crimson, tipped white. Petals long and gracefully arranged in an unusual attractive manner.

$\$ 2.00$

ANASTASIA, R. $\quad 5 \frac{1}{2} \mathrm{ft}$. Redding. A giant hybrid cactus of beautiful form. Color soft canary yellow. Plants are very robust and hold their blooms well above the foliage.

$\$ 1.00$

ATTRACTION. 4ft. Hornsveld. A large splendid flower of beautiful form and color. Blooms very erect on long canelike stems. Color clear lilac-rose or orchidpink. A favorite.

$50 \mathrm{c}$

BABA BOTT.

$3 f t$.

Murphy.

One of the freest flowering dahlias. An immense flower but soon grows small unless the blooms are cut frequently. Color pink shading to white.

$35 \mathrm{c}$

BABE RUTH. $5 \mathrm{ft}$. Finger. One of the best yellow dahlias for cutting. The blooms are medium size, of perfect form and produced in great quantities on long stems that hold blooms perfectly erect. Color picric yellow.

$\$ 1.00$

BALD EAGLE, R. 3ft. Redding. Distinct new hybrid. Large bold flowers of fine form and great depth. Color crimson, tipped white. The white tips are very irregular but it is a fine flower and well worth growing.

$\$ 2.00$

BIANCA.

$5 \mathrm{ft}$.

Hornsveld.

Every one should grow this splendid dahlia. It is unsurpassed for garden display or as a cut flower. An abundant bloomer on long straight stems. Color rosy-lavender. .... $50 \mathrm{c}$
BREAK OF DAY. 41/2ft. Dahliadel. Color clear sulphur yellow shading to cream the whole flower illuminated with a satiny sheen. A free bloomer that requires cutting freely to retain its large size.

$50 \mathrm{c}$

\section{CALIFORNIA ENCHANTRESS.}

$4 \mathrm{ft}$. Bessie Boston. This beautiful dahlia is a model flower, its size, form, color, stem and habit of growth is all that could be desired for garden decoration, exhibition or cutting. Color twotoned pink.

$\$ 1.00$

CIGARETTE. $5 \mathrm{ft}$. Bessie Boston.

An unusual attractive variety, perfectly erect on long straight stems. Color creamywhite, distinctly edged with orange. Fine for cutting.

$\$ 1.00$

CHRISTMAS TIME, R. $\quad 3 \frac{1}{2} \mathrm{ft}$. Redding. This new hybrid is one of the finest of the bi-colored dahlias. A very beautiful flower of graceful form. Color carmine-red, heavily tipped with white.

$\$ 2.00$

COLOSSAL PEACE. 5 $\frac{1}{2} \mathrm{ft}$. Dahliadel. Color creamy-white, shaded to rose-pink and lighter at the tips. A giant hybrid cactus early in the season but later the blooms are all open centered. Very beautiful in either. form.

$75 \mathrm{c}$

CREAM WHIP, R. 3ft. Redding. A new giant hybrid cactus of wonderful grace and beauty. Form quite distinct with long irregular petals. Color cream, shaded with buff and salmon.

$\$ 3.00$

DADDY BUTLER. 4ft. Bessie Boston. Color an American Beauty rose shade, the reverse of the petals a much lighter shade, The petals are so rolled that the reverse color is very prominent giving the flower an attractive two toned effect.

$\$ 1.00$

DIANA. $\quad 3 \frac{1}{2} \mathrm{ft}$. Hornsveld. An extra large flower of distinct formation. Color crimson with violet shadings. A very free bloomer on long stiff stems that hold the flowers very erect.

$50 \mathrm{c}$

EASTERN BEAUTY, R. 5ft. Redding. Color a pleasing blending of autumn-pink and yellow shades. Makes a fine bushy plant that is covered with its large beautiful flowers the whole season. 
EDNA FERBER. 4ft. Fisher \& Mason. An exhibition hybrid cactus of extreme size on a fine strong stem. Color a glistening coral shading to old gold at the base of the petals. A winner of a great many first prizes. A beauty.

$\$ 2.00$

EDITH SLOCUMBE. $3 \mathrm{ft}$. Slocumbe. Distinct both in color and formation. Color burgundy or fuchsia-red. Petals greatly twisted and curled. A lovely flower but the stems are pendant.

$50 \mathrm{c}$

ELSIE DANIELS. $3 \mathrm{ft}$. Meachem. One of the most beautiful dahlias. Color pale violet-orchid, shaded to pure white at the center. An artistic flower of very graceful formation. Free bloomer of all giant flowers.

$\$ 1.00$

ELSIE OLIVER. $5 \mathrm{ft}$. Bessie Boston. A niodel hybrid cactus. One of the largest and finest of its type. An exhibition dahlia of highest rank. Color creamy-pink, shading to cream at the center. Good free bloomer on good stems.

$\$ 1.00$

EMMA MARIE. $51 / 2 \mathrm{ft}$ Dahliadel. One of the finest dahlias for cutting: A robust grower, producing quantities of fine flowers on exceedingly long straight stems. Color clear pink shading to a creamywhite center.

$\$ 1.00$

ENTENDARD DE LYON. 5ft. Rivoire. Color rich roval purple with a briliant rose-carmine suffusion, rather difficult to describe. Very popular flower in the gardens. A profuse bloomer on the best of stems for cutting.

$50 \mathrm{c}$

FRANCES LOBDELL. 3ft. Waite. This splendid flower ranks with the best. Large beautiful flower of perfect form on upright stem. Very free bloomer of all fine flowers. Color mallow-pink shading to white at center.

$\$ 1.00$

FIRE CHIEF.

$3^{1} \cdot 2 \mathrm{ft}$.

Redding.

This new rea hybrid will be hard to beat. A model flower of deep rich red color on a good stem.

$\$ 1.00$

GALEATEA.

$4 \mathrm{ft}$.

Bessie Boston. A very handsome dahlia. Color soft yellow, sometimes tinted with pink. Giant flower with very long narrow petals that are gracefully waved. Distinct.

$\$ 1.00$

GEE WHIZ.

$5 \mathrm{ft}$.

Broomall. An immense, heavy flower on very strong straight stems. Color soft buff with a light salmon suffusion.
GEN. PERSHING.

$5 \mathrm{ft}$.

Dahliadel.

Color creamy-white without shading. In form it is nearly that of the decorative. Free flowering.

$25 \mathrm{c}$

GEO. WALTERS.

$41 / 2 \mathrm{ft}$.

Walters.

There is no finer dahlia grown; an ideal variety of the finest type, excellent for exhibition, garden decoration or cutting. Color pinkish-salmon, suffused with gold. Makes a fine bushy plant that is always full of giant blooms, every one perfect and having the best of stems

$\$ 1.00$

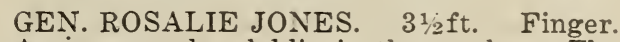
$A$ very popular dahlia in the gardens. The blooms are large, of refined form, a blending of the true and hybrid types. Color a clear bright yellow.

$\$ 1.00$

GLADYS BATES. 31/2ft. Bessie Boston. An immense, heavy bloom of attractive formation, almost that of the true cactus, long incurved petals, very deep centered. Color a very pleasing blending of $\tan$ and rose reverse.

$\$ 1.00$

GLADYS SHERWOOD. 3ft. Broomall This is still the largest and best pure white hybrid cactus. A beautiful flower of distinct form, erect on straight stems. Fine for exhibition.

$\$ 1.00$

GLORY OF AMERICA, R. 4ft. Redding. An enormous deep full centered hybrid. A seedling from Geo. Walters, much deeper centered and darker in color. Difficult color to describe, mulberry-red perhaps best describes it.

$\$ 2.00$

GOLDEN WEST. $4 \mathrm{ft}$.

Broomall. Color deep yellow, overlaid orange. An excellent dahlia for any purpose. Blooms upright on good stems.

HIGHLANDER. 3 ft.

Redding. Color wine crimson, light reverse. Points of petals twisted so that the flower seems to be tipped white. A medium size flower on upright, rather short stems.

$50 \mathrm{c}$

HONEYMOON, R. 31/2ft. Redding. This is a very refined, beautiful dahlia of soft delicate colors, cream suffused lavender. Large fine flower, free flowering on good stems.

$\$ 2.50$

JUNE BRIDE, R. $4 \frac{1 / 2}{\mathrm{ft}}$.

Redding. Large pure white hybrid with long, narrow straight petals. Form nearly that of the true cactus. Blooms erect. .................... $\$ 1.00$ 
KALIF. $\quad 5 \mathrm{ft} . \quad$ Englehardt.

A truly majestic flower, its bold giant flowers standing erect on long straight stems well above the foliage. Color clear bright red.

$50 \mathrm{c}$

KOH-I-NOOR. $\quad 4 \frac{1}{2} \mathrm{ft} . \quad$ Bessie Boston. Color dark maroon. Large fine flowers, one of the best of its color. Blooms very freely and every flower perfectly double throughout the season.

$75 \mathrm{c}$

KALEIDOSCOPE, R. $3 \frac{1}{2} \mathrm{ft}$. Redding. Huge new fancy hybrid, a massive flower with very deep full centers. Color straw striped and splashed red.

Sold Out.

LADDIE BOY, R. 4ft. Redding. Color pure bright yellow without shading. This wonderful giant flower has always been a great favorite in the gardens, everyone stops to admire it.

$\$ 1.00$

LADY JOAN, R. 4ft. Redding. Large beautiful dahlia of delicate color, a lovely blending of lavender-pink and cream shades. Free flowering with good stems for cutting.

$\$ 2.50$

LADY HELEN.

$5 \mathrm{ft}$.

Stillman.

One of the best. A large flower of finest form, and great beauty. Habit upright, its long straight stems holding its giant flowers well above the foliage. Color pinkish old rose with cream shadings.

$\$ 1.00$

LA FAVORITE. 3ft. Lohrmann. An extra early and free flowering variety of orange-salmon color.

$25 \mathrm{c}$

LAURINE. $\quad 3 \frac{1}{1} 2 \mathrm{ft}$. Broomall. Color a beautiful deep pink that every one stops to admire. A large bold flower of fine form. Excellent for garden or for exhibition.

$\$ 1.00$

LIBERTY BELL. 4ft. Dahliadel. Distinct in color, soft carmine-rose, shading to yellow at base and tips.

$50 \mathrm{c}$

LORNA SLOCUMBE. $3 \frac{1}{2} \mathrm{ft}$. Slocumbe. An immense flower of wonderfud formation and color. Orange with apricot shadings. Very striking.

$\$ 2.00$

MADONNA. $\quad 4 \frac{1}{2} \mathrm{ft}$. Ware. An excellent variety for garden display or for cutting. A very graceful flower with long waving petals. Color waxy-white. One of the freest bloomers.
MARIPOSA. $5 \mathrm{ft}$ Bessie Boston. Color a delicate pink shade that deepens towards the center, a faint violet suffusion adding to the effect. One of the largest and most beautiful dahlias of this type. Very popular.

$\$ 1.00$

MRS. C. H. BRECK. 3ft. Peacock. Color carmine with rose and white suffusions, shaded yellow at the base. An attractive flower of medium size, a wonderful free bloomer on good stems. Makes a very fine display in the garden. $50 \mathrm{c}$

MRS. ETHEL F. T. SMITH. $5 \frac{1}{2} \mathrm{ft}$.

Broomall.

One of the most admired dahlias in the gardens. An immense flower that is borne freely on long stems, erect above the foliage. Color creamy-white shading to lemon at the center.

$75 \mathrm{c}$

MRS. RICHARD LOHRMANN. $3 \frac{1}{2} \mathrm{ft}$.

Lohrmann.

Color pure golden yellow. A very large dahlia of regular form. Color pure goldenyellow. Good stems.

$75 \mathrm{c}$

MRS. WARNARR. 3ft. Hornsveld. Beautiful old standard of graceful form, petals very artistically arranged. Color creamy-white with pink tints.

MRS. W. E. ESTES. 6ft. Estes. Tall growing variety holding its blooms high up on long stems. Color pure white. A refined flower.

$50 \mathrm{c}$

MT. SHASTA. $\quad 5 \frac{1}{2} \mathrm{ft}$ Stillman.

Heavy built flower of hybrid formation many flowers showing open centers. Color light shell-pink, shaded deeper and to yellow at the center.

$35 \mathrm{c}$

NATIVE SON, R. $5 \frac{1}{2} \mathrm{ft}$. Redding. Distinct new introduction having the Geisha colors in a very attractive combination, scarlet and yellow. Very good for cutting blooming freely the whole season on long upright stems.

$\$ 1.00$

NIBELUNGENHORT. 5ft. Englehardt. A large fine flower that is always admired for its beautiful color, a lovely shade of old-rose with golden-apricot suffusions. Blooms very freely.

$50 \mathrm{c}$

NORTH STAR. $6 \mathrm{ft}$.

Redding.

Tall robust grower holding its flowers well above most dahlias. Color clear soft yellow. Nicely formed flower. $\$ 1.00$ 
PAPILLON.

$3 \mathrm{ft}$.

Bessie Boston. A great big flower that is well worth grow. ing. Color a beautiful shade of old rose, suffused with gold. A constant bloomer all season, good stems.

$\$ 1.00$

PLYMOUTH BEAUTY, R. 31/2ft. Redding. A lovely variety that has always been a favorite. Seedling from Colossal Peace. Color rose-pink shading to white towards the center. Large flower with broad, flat petals that curve back.

$\$ 1.00$

PLYMOUTH ANGLE, R. 31/2ft. Redding. One of the largest yellow hybrid cactus dahlias. Very deep as well as broad and of wonderful form. Color a beautiful clear yellow. One of the best.

$\$ 10.00$

PREMIER CLEMENCEAU. 51/2ft. Brown. Generally listed as hybrid cactus although it is nearer the true cactus in form. The flower is of medium size but one of the most attractive in color, bright lemon-yellow distinctly tipped white.

$\$ 1.00$

PRIMROSE. $\quad 3 \frac{1}{2} \mathrm{ft}$. Redding. Color pure primrose yellow. Large flower on upright stems. One of the earliest and freest bloomers.

PRIDE OF DAHLIADEL. $\quad 5 \frac{1 / 2 \mathrm{ft} .}{}$

Dahliadel.

A dahlia of great merit, deep full center. Color rich carmine-red.

$75 \mathrm{c}$

RED CROSS. $5 \mathrm{ft}$ Anderson. Color old gold, shaded yellow and suffused scarlet. Large and fine

$75 \mathrm{c}$

ROLLO BOY.

$5 \mathrm{ft}$.

Pelicano.

Monster flower, one of the real big ones. Color golden yellow. Has won many prizes as largest flower.

$\$ 1.00$

ROYAL LADY, R. $\quad 51 \frac{1}{2} \mathrm{ft}$. Redding. In form a blending of the true cactus and hybrid types. A giant flower, deep as well as broad, and nicely formed, somewhat incurved. Color royal purple with lighter shadings. Free flowering.

$75 \mathrm{c}$

ROYALTY.

$3 \mathrm{ft}$.

Redding.

Medium size flower of quite regular form, erect on straight stems, fine for cutting. Color royal purple.

$\$ 1.00$

RUTH VAN FLEET.

$6 \mathrm{ft}$.

Stillman. An excellent variety with all good points. Large graceful flower on very long straight stems. Color soft canary yellow.
SCARLET RIDER.

$5 \mathrm{ft}$.

Redding.

Color clear bright red, shading to yellow at base of petals. A giant flower of attractive formation.

$75 c$

SILVERADO.

$51 / 2 \mathrm{ft}$.

Seal.

One of the very largest in this class. A wonderful flower in size, color and formation. Color white, shaded to a delicate silvery-lavender at the center.

$\$ 2.50$

STATIC. $4 \mathrm{ft}$.

Rodding.

Large nicely formed hybrid, deep and full double. Color bright crimson.

$\$ 1.00$

SUNKISS.

$4 \mathrm{ft}$.

Childs.

Large attractive flower. Color rosy-salmon, shading to yellow towards the center. Stems rather pendant.

$\$ 1.50$

SISKIYOU.

$4 \mathrm{ft}$.

Broomall.

Probably the largest dahlia ever introduced. Has created a sensation at the exhibitions and in the gardens. A sturdy plant of medium height that holds its immense flowers perfectly erect on strong stems. Color pink, tinted mauve.

$\$ 1.00$

SUNSET GLOW. $3 \frac{1}{2} \mathrm{ft}$. Peacock. Color scarlet with yellow at the base and at the tips. A flower similar to Red Cross, but better in every way. Very free flowering and good stems.

$75 \mathrm{c}$

SUNNY SOUTH. $3 \frac{1}{2} \mathrm{ft}$. Broomall. Large bold flower of good form and stem. Color clear golden-yellow.

$\$ 1.00$

THE BANDIT. 5ft. Reed. Large exhibition dahlia. Color spectrumred, reverse of petals buff-yellow, which curl and twist showing the reverse color giving it the appearance of two colors. Upright habit, free flowering.

$\$ 1.00$

THE EAGLE.

$4 \mathrm{ft}$.

Burns.

Color pure sulphur-yellow. Very large variety of graceful formation, petals long and narrow, making an attractive Chrysanthenum-like flower.

$50 c$

THE KING, R.

$$
31 / 2 \mathrm{ft} \text {. }
$$

Redding. A model hybrid cactus. An ideal flower, of perfect form, good size, stem and habit of growth. Color deep rich crimson, shading to maroon at the center.

$\$ 2.50$

THE ORCHID, $R$. $4 \mathrm{ft}$.

Redding. A beautiful new hybrid of large size and splendid form. Calor orchid-pink shading to white at the center. Free bloomer on good stems. 

TOM LUNDY. $\quad 31 \frac{1}{\mathrm{ft}}$. Fenton. habit. Large fine flower. Color deep crimsoncarmine.

$50 \mathrm{c}$

U. S. A.

$5 \mathrm{ft}$.

Stillman.

Probably no other dahia has met with greater favor than this variety. Color deep bronzy-orange. This big shaggy hybrid is an ideal flower for any purpose, blooming freely'for garden display, good stems for cutting and of giant size for exhibition, and keeps well after cutting.
WALKUERE.

$51 / 2 \mathrm{ft}$.

Englehardt.

One of the largest and most graceful dahlias. An artistic flower with numerous long waving petals. Color primrose, lightly tinted rose. Long upright stems.

$50 \mathrm{c}$

WASHINGTON CITY. 4ft. Broomall. An immense pure white of quite regular form, nearly that of the decorative. ..... $50 \mathrm{c}$

WODAN. 5ft. Goos \& Keoneman. Color delicate salmon-rose shading to oldrose at the center. Very free flowering. A beautiful dahlia.

\section{Cactus Dahlias}

AMBASSADOR. $5 \mathrm{ft}$ Broomall.
One of the largest cactus dahlias. Color soft yellow-buff, lightly shaded salmonpink and amber. Stems long and straight, blooms erect.

$\$ 1.00$

BALLET GIRL. 5 $1 \frac{1}{2 \mathrm{ft} .}$ Bessie Boston. Color pure white, edged orange, varying in many combinations, from all white to a solid orange. An immense incurved cactus, very deep and full centered. Blooms well up on long stems.

$50 \mathrm{c}$

BONNIE G. 4ft. Bessie Boston. A dahlia of exquisite beauty. Color a clear light pink without shading. Early and continuous bloomer all season. Every one should grow this beauty.

$\$ 1.00$

BETTY AUSTIN. $3 \frac{1}{2} \mathrm{ft}$. Peacock. A very charming variety that is always admired. Its beautiful form and color and its free flowering habit making a very desirable variety for any purpose. Color rosy-carmine shading to yellow at the base and tips.

$75 \mathrm{c}$

CHAS. SHERBROOK. $6 \mathrm{ft}$. Oregon. An American novelty of striking color, bright scarlet, base of the petals golden yellow, reverse gold.

$75 \mathrm{c}$

COCKATOO. $4 \mathrm{ft}$ Dobbie. Color yellow at the base of the petals, changing to fawn, and again to pure white at the tips. A very nice flower of distinct form. Very popular. $25 \mathrm{c}$

COUNTRY GIRL. 3ft.

Dreer. Color pure golden-yellow, the center petals tipped with bright scarlet. Excellent garden variety.
CRYSTAL.

$4 \mathrm{ft}$.

Stregwick. An ideal flower for garden decoration. A very free blocmer, blooms large and of the finest incurved form. Color silvery-pink, shading to white at the center and again to white at the tips.

FARNCOTT. 4ft. Frazer. Color aster purple evenly tipped white. A distinct new variety of good size, perfect form and the freest flowering habit. Blooms carried face up on top of good straight stems. Very fine.

$\$ 1.00$

F. W. FELLOWS. 51/2 ft. Stredwick. A wonderful exhibition cactus of immense size. Color bright orange. Blooms very deep and always perfectly double. Habit of growth upright holding its flowers well above foliage. One of the very best cactus dahlias.

$75 \mathrm{c}$

GOLDEN CROWN. 3ft. Stredwick. Color pure golden yellow. Fine incurved variety. Free flowering. $50 \mathrm{c}$

GOLDEN EAGLE. 51/2ft. Stredwick. Color golden yellow suffused rosy-fawn. A profuse bloomer of model flowers that are held quite erect on long stems. $35 \mathrm{c}$

J. H. JACKSON. 4ft. Vernon. A very popular dark variety that is always in demand. Color velvety crimson, almost black. One of the best garden dahlias, always a mass of blooms.

LOLITA VALESCO. 5ft. Bessie Boston. The finest pure white cactus dahlia, straight petaled variety of giant size, standing erect on long stems. .............................. $\$ 1.00$ 
MAMMY, R. $\quad 5 \mathrm{ft}$ Redding. In this new cactus dahlia we have one of the darkest grown, very dark velvety maroon, almost black. Large graceful flower of incurved type. Free bloomer. $\$ 1.00$

MAYFLOWER, R.

$5 \mathrm{ft}$.

Redding. One of the largest and finest incurved cactus dahlias. Petals are exceedingly long, narrow and gracefully incurved and twisted. Color white delicately suffused with lavender-pink. Very free flowering.

$\$ 5.00$

MARGUERITE BUCHON 5ft. Cayeux. Color a beautiful shade of bright rose with a pure white center and distinct white tips. Blooms of good size, quite regular in formation, petals very long, narrow and straight. A very popular dahlia.

$75 \mathrm{c}$

MERCURY.

$5 \mathrm{ft}$.

Stredwick.

Flower of unusual formation, the petals are greatly incurved, twisting and curling orer the center giving it a very shaggy appearance. Color yellow, splashed and speckled with crimson. Odd and striking.

$50 \mathrm{c}$

MISS DIMITY.

$3 \mathrm{ft}$.

Redding.

In this new variety we have something that is different. Color pure white, thickly striped and speckled crimson. A very pretty flower of medium size. One of the freest flowering dahlias.

\section{MISS SPORT.}

$3 \mathrm{ft}$.

Redding.

This new variety is like Miss dimity in every respect but color. Pure white splashed and speckled with pink.

$75 \mathrm{c}$

MME. CAYEUX.

5ft.

Cayeux.

Color deep pink, shading to white. An extra good cutting variety, blooming very early and free on long upright stems.

$35 \mathrm{c}$

MRS. ALFRED HARVEY. $51 / 2 \mathrm{ft}$.

Stredwick.

Color light salmon-pink with darker shadings at the base of the petals. One of the finest of the narrow petaled, incurved cactus dahlias. Long stems.

$\$ 1.50$

MRS. F. JEFFRIES.

$3 \mathrm{ft}$.

Wilmore. An American cactus, type nearly that of the hybrid cactus. Color deep velvety gar:et. Peteis artistically arranged.

$85 \mathrm{c}$

OLYMPIC. $\quad 5 \mathrm{ft}$.

Stredwick. An English exhibition cactus of highest rank, a giant flower with very long narrow petals, greatly incurver lor deep crimson, Upright habit.
PATHFINDER.

$5 \mathrm{ft}$.

West.

An English incurver cactus dahlia of perfect form and beautiful color; soft pink. Large and fine.

$\$ 1.00$

PHENOMENAL.

$5 \mathrm{ft}$.

Stredwick.

Color beautiful shade of pale salmon with yellow base and yellow tips. An unusual variety, the petals are so long and ribbon-like that they form a tangled mass over the center, making the flower look more like a huge chrysanthemum.

$\$ 1.50$

PIERROT. $\quad 5 \frac{1}{2} \mathrm{ft}$.

Stredwick. Color deep amber, shaded to yellow and distinctly tipped white. One of the largest and finest of the English cactus dahlias, the petals greatly incurved. A very attractive variety. Free flowering.

$50 \mathrm{c}$

RED COAT.

$4 \mathrm{ft}$.

Stredwick. Color bright glowing red. An exceptional fine garden dahlia.

\section{RHEINESCHER FROHSINN. $5 \mathrm{ft}$.}

Goos \& K. Color a bright carmine-rose, shaded to a pure white center. A very attractive variety of incurved form.

$75 \mathrm{c}$

RHEINKONIG. $\quad 3 \frac{1}{1 / 2} \mathrm{ft}$. Goos \& $\mathrm{K}$. Pure snow-white. Medium size flower in form nearly that of the hybrid cactus. $35 \mathrm{c}$

\section{ROBIN. $\quad 4$ ft.}

Stredwick. A miniature cactus dahlia, seldom measuring over two inches in diameter. A perfect little model cactus. Color deep robin breast red. Early and free flowering.

$35 \mathrm{c}$

SHERLOCK. $2 \frac{1}{1 / 2}$ ft. Stredwick. Color orange-scarlet. Plants grow very low but produces its large flowers very freely all season.

$35 \mathrm{c}$

SILVERHILL PARK. 5ft. Stredwich. $T_{\text {iL }}$ best pure white incurved cactus dahlia. A large finely formed flower on very good stems.

$\$ 1.50$

ST. ELIAS.

$4^{1} . \mathrm{ft}$

Mastic. Color pure white, good size and incurved. A good all around white cactus. An early and free bloomer.

$50 \mathrm{c}$

WASHINGTON.

$5^{1 / 2} \mathrm{ft}$.

Stredwick.

An incurved English cactus dahlia of high rank. Plants robust, branching freely and produces its large, perfectly double flowers in abundance on long wiry stems. Color deep crimson. 


\section{COLLARETTE DAHLIAS}

ACHIEVEMENT.

$5 \mathrm{ft}$.

Alexander.

One of the very best collarette dahlias. Color deep maroon with distinct white collar petals. Very free.

$25 \mathrm{c}$

EDDYSTONE.

$5 \mathrm{ft}$.

Dobbie.

Color crimson lightly tipped with yellow, collar petals white. A splendid variety. Always in bloom.

$35 \mathrm{c}$

FAIRY.

$4 \mathrm{ft}$.

Redding. Color pure white suffused rose and white at the tips. Collar petals rose and white. Very attractive.
HERON.

$5 \mathrm{ft}$.

West.

Color bright crimson, collar petals white splashed with crimson.

$25 \mathrm{c}$

SWALLOW.

$5 \mathrm{ft}$.

Stredwick. Color pure glistening white with collar petals the same. An extra fine collarette. Upright on long stems.

$35 c$

WM. WELSH. $4 \mathrm{ft}$. B. Boston. Color pure lemon yellow with the collar petals of a lighter shade. The best of its color. $50 \mathrm{c}$

\section{PAEONY FLOWERED DAHLIAS}

\begin{abstract}
BILLIONAIRE.
$51 / 2 \mathrm{ft}$

Stillman. An immense flower of graceful formation. A great favorite with those that like the paeony flowered dahlia. Very free flowering. Color clear gold.

$\$ 1.00$
\end{abstract}

BLUE BIRD.

$5 \mathrm{ft}$.

Bessie Boston. An exceptional color of the deepest tone of lilac, which in certain lights has a bluish sheen. Large fine flowers on long stems well above foliage.

$50 \mathrm{c}$

CARDINAL MERCIER. 5ft. Stillman. An exhibition paeony of largest size and wonderful form. Color deep flesh-pink, suffused with canary yellow. One of the best of this class.

$\$ 1.00$

CITY OF PORTLAND. 4ft. Chamberlain. A grand variety that is always admired for its giant size and wonderful form. Color bright yellow. The largest and finest yellow paeony dahlia.

$\$ 1.00$

EDITH CAVELL.

$4 \mathrm{ft}$.

West.

Large flower of good form, many of the blooms coming double. Color old gold shaded reddish-bronze.

$50 \mathrm{c}$

\section{ELIZABETH BOSTON. 51/2ft. \\ Bessie Boston.}

Giant dahlia of great depth. Color crimson shaded gold at the tips. Erect on a long stem. A favorite.

$75 \mathrm{c}$

EMPRESS OF ASIA. 31/2ft. Stillman. Color deep golden-bronze. Large distinct variety. Free flowering.
GEISHA.

$5 \mathrm{ft}$.

Hornsveld.

The showiest and most popular paeony dahlia. A large graceful flower of striking color, yellow shading to scarlet and to gold at the tips.

$75 c$

GORGEOUS. $\quad 5 \frac{1}{2} \mathrm{ft}$. Bessie Boston.

Well named as it is certainly a gorgeous flower. Color yellow and scarlet blended in a wonderful manner. Plants robust, its extra long cane-like stems holding its giant blooms erect.

$\$ 1.00$

GREAT EASTERN, R. 5ft. Redding. A model paeony of largest size and finest form. Color a lovely shade of rosy-lavender. Good stems.

$\$ 1.00$

J. D. ROCKEFELLER. 4ft. Burpee. An ideal flower for cutting. Medium size flower on straight stems. Color salmonpink and amber. $35 c$

LAURA BARNES. 5ft. Wilmore. Color bright orange with a yellow center. One of the freest bloomers. $50 \mathrm{c}$

LADY CARDINE. $\quad 4 \frac{1}{2} \mathrm{ft}$. Stillman. A very showy variety of large size and attractive color, rich carmine-red, each petal tipped white to about half its length. Makes a fine display.

$\$ 1.00$

MAID OF JAPAN, R. 4ft. Redding. An unusual dahlia that is always admired for its wonderful color and form. The color is a very attractive combination of red and yellow. This is really a single variety but owing to its formation I have always listed it as a paeony. $\$ 1.00$ 
NAIAD.

$5 \mathrm{ft}$.

Wilmore.

Color a delicate blending of cream and flesh-pink. Large and fine and upright on good stems.

$35 c$

N. C. 4 .

$4 \mathrm{ft}$.

Stillman.

An unusual attractive blending of colors red, yellow and white. An excellent garden variety.

$75 \mathrm{c}$

\section{PEARL RUGGLES.}

$5 \mathrm{ft}$.

Ruggles. An artistic flower of wonderful grace and beauty. Color carmine-rose, suffused on a white ground, changing to a lighter shade on the outer edge of the petals. Large flower on an erect stem.

$\$ 1.00$

PEG O' ME HEART. 51/2ft. Marean. Different both in form and color, excellent for cutting. Color old-rose, with a golden suffusion.

$35 \mathrm{c}$

\section{PACIFIC GLOW.}

$4 \mathrm{ft}$.

Burns. An extra large distinct flower. Color pink with buff shadings on center petals that twist and curl over the yellow center. Free flowering.

$75 \mathrm{c}$

QUEEN ELIZABETH. 5ft. Peacock. An excellent garden or cutting variety. Very free flowering on perfectly straight stems. Color lavender-pink.

$25 \mathrm{c}$

QUEEN WILHEMINA. $5 \mathrm{ft}$. Hornsveld. Color pure white. A large, very graceful, artistic flower.

$25 \mathrm{c}$

RED WING. $\quad 4 \frac{1}{2} \mathrm{ft}$. Redding. Color clear crimson-maroon. About the best of the red paeony dahlias. Very large and free flowering.

RENE.

$4 \mathrm{ft}$.

Redding.

Color pure deep lavender, a shade that is always admired. A model flower of this type. Free and early.

$50 \mathrm{c}$

ROSALIE STYLES. $\quad 4 \frac{1}{2} \mathrm{ft}$. Peacock. A colossal paeony, one of the largest and best in this class. In color a beautiful tyrian-pink, tipped lighter. An ideal garden variety.

$50 \mathrm{c}$

SALLY.

$5 \frac{1}{2}$

Redding.

Color bronze-orange shading lighter. Large fine flower that often comes with full centers. Blooms erect on very long stems. An excellent cutting variety.
SALMON QUEEN.

$5 \mathrm{ft}$.

Redding.

A monster flower on long stems but slightly pendant. Color apricot-salmon with golden suffusions. Very fine.

$\$ 1.00$

SNOWMAN, R.

$4 \mathrm{ft}$.

Redding.

Color pure glistening snow-white. A giant flower of excellent formation. Petals very broad and waved.

$\$ 1.00$

SUSAN COE.

$3 \frac{1}{2}$

Burpee.

A splendid paeony of giant size. Many of its blooms are perfectly double here. The outer petals are a pleasing shade of rosepink, shading to yellow at the center, suffused salmon. Blooms very erect on long straight stems.

$50 \mathrm{c}$

TERCENTENARY, R. $5 \frac{1}{2} \mathrm{ft}$. Redding. An immense flower or original form, about the broadest, flatest flower grown. Color a beautiful combination of flesh-pink and cream. The outer petals are broad and flat, the inner petals very irregular and twisted and curled about the yellow center. The stems are pendant.

$\$ 2.00$

THE ORIOLE. $\quad 31 / 2 \mathrm{ft}$. Burns. Color an attractive combination of burntorange and yellow, occasionally tipped white. This variety was introduced as a paeony flowered dahlia but in my fields most of the flowers are full centered hybrid cactus. A very beautiful flower.

$\$ 1.00$

UNCLE SAM. $5 \frac{1}{2} \mathrm{ft}$.

Meachem. A wonderful paeony flowered variety of the largest size. Blooms very freely on very long stems, every one a giant. Color orangebuff at the base of the petals, shaded to bittersweet-pink at the tips, overlaid with a golden sheen, center petals mustard yellow, streaked rose, the reverse spinal-red. One of the very best.

$\$ 1.00$

VENUS.

$5 \frac{1}{2}$

Redding. Color pure canary-yellow. An exceptional large free flowering variety that has always been very popular.

WEDDING DAY. $5 \mathrm{ft}$.

Redding. Color wine crimson, heavily tipped pure white, varies somewhat in each flower. A free bloomer.

$50 \mathrm{c}$

YELLOW WARBLER. 5ft. Redding. A large paeony dahlia on long straight stems. Color bright yellow. 


\section{Single Dahlias}

ECKFORD CENTURY. 4ft. Peacock. Color pure white ground, thickly striped and spotted crimson. $25 \mathrm{c}$

GOLD STAR, R. $5 \mathrm{ft}$.

Redding. Color pure white, edged with a band of pure gold. Stands perfectly upright on long straight stems. Fine variety.

$\$ 1.00$

HALO.

$4 \mathrm{ft}$.

Redding.

Color scarlet with a broad yellow halo about the yellow center.

$50 \mathrm{c}$

LEMON STAR.

$5 \mathrm{ft}$.

Redding. Color lemon yellow. Resembles a giant cosmos. Very free.

$50 \mathrm{c}$

PINK STAR.

$5 \mathrm{ft}$.

Redding.

Color pure pink. About the best pink single variety. Long straight stems.

$50 \mathrm{c}$

PRINCESS.

$6 \mathrm{ft}$.

Redding.

Clear rich plum shading to violet at the tips. Long stems.

$35 \mathrm{c}$

NEWPORT WINNER. 5ft. Alexander. Color crimson with yellow center. Extra free flowering.
RED STAR.

$5 \mathrm{ft}$.

Redding.

An extra good new single of pure crimson color. Free flowering, upright stem.

$35 \mathrm{c}$

SENSATION. $5 \frac{1}{2} \mathrm{ft}$. Bassett. A very striking flower having one or two rows of petals. Color bright scarlet, heavily tipped white. Contrasting colors making a very attractive display.

$50 \mathrm{c}$

SPANISH LADY. 4ft. Redding. A giant fancy single of unique color, bright yellow, thickly stripped and splashed with crimson. Very striking.

$50 \mathrm{c}$

WONDER STAR.

$6 \mathrm{ft}$.

Redding. A beautiful new single that all lovers of the single dahlia will want. Color pure white, the edges of the petals bordered with magenta. Perfectly upright on long stems.

$\$ 1.00$

WHITE STAR.

$5 \mathrm{ft}$.

Redding.

Color pure white. The best pure white single Stems long and straight.

$50 \mathrm{c}$

YELLOW STAR. $\quad 51 \frac{1}{2} \mathrm{ft}$. Redding. A new pure yellow single that will be hard to beat. Blooms erect on long straight stems. Clear canary yellow.

$50 \mathrm{c}$

\section{Show Dahlias}

AM. BEAUTY. $\quad 3 \frac{1}{2} \mathrm{ft} . \quad$ F. F. \& R. Color wine-crimson, shaded deeper. A large double flower on good stems for cutting. An old favorite.

$25 \mathrm{c}$

ARTHUR LAFAVOUR. 5ft. Alexander. Color yellow, thickly stripped and splashed with crimson. An unique flower of very large size.

$25 \mathrm{c}$

BERTHA BERNSTEIN. 5ft. Gero. Very large double flowers of stout, straight stems. Color light lavender.

$20 \mathrm{c}$

BONNY BLUE. $\quad 3 \frac{1}{2} \mathrm{ft}$. Storrs \& H. One of the near blue dahlias, color bluish purple. Blooms perfectly round balls, very free flowering on good stems, fine for cutting. Very popular.

$35 c$

CHEERO.

$3 \mathrm{ft}$.

Redding.

A grand new show dahlia of very striking color, rose heavily tipped with pure white. A very large show that must be seen to be appreciated.
CREAM OF VALLEY. 5ft. Dreer. Large distinct flower. Color creamy-white, shading gradually to crimson at the tips. Very attractive.

$25 \mathrm{c}$

CREAM PUFF. $5 \mathrm{ft}$.

Redding.

This new giant hybrid show is attracting a great deal of attention. In form nearly that of the decorative. Color pure rich cream. A beauty.

$\$ 1.00$

CUBAN GIANT. $5 \mathrm{ft}$. Storrs \& H. A flower of large size with deep full center's. Color dark mar won.

$20 \mathrm{c}$

DOROTHY PEACOCK. 41/2ft. Peacock. One of the finest of this class for cutting purposes. Erect or very long cane-like stems. Color sheil pin shading off to pure white.

$25 \mathrm{c}$

DREER:S WHITE.

$3 \mathrm{ft}$.

Dreer.

Color pure glistening white. A giant hybrid with beautifully fluted petals. Or: of the freest bloomers. 
EBENEZER.

$5 \mathrm{ft}$.

Redding.

Distinct new variety, different from any other color, an odd mixture of red and white, also yellow at times. Blooms very erect on long straight stems.

$25 c$

EDWARD LAFAVOUR. 4ft. Warien. A large fancy hybrid show of unusual color, deep bronze-yellow ground, thickly striped and splashed with red.

$50 \mathrm{c}$

ESTELLE CHRISTY. $5 \frac{1}{1} \mathbf{2} \mathrm{ft}$. Alexander. The best yellow show yet produced. A giant flower of perfect full double formation. Free bloomer on good stems. Excellent for garden or cutting.

$50 \mathrm{c}$

FRANK SMITH.

$5 \mathrm{ft}$.

Schmitz. Color dark maroon, almost black, sometimes tipped white.

$25 c$

FREDA. $31 / 2 \mathrm{ft}$.

Redding. A new ball-like flower on good stems for cutting. Color lavender, shading to white at the base of petals.

$25 c$

GEN. MILES.

$5 \mathrm{ft}$.

Stillman.

The largest and best fancy show yet produced. Color violet-rose, thickly striped and splashed magenta. This wonderful flower has always attracted a lot of attention. Exhibition dahlia.

$75 c$

GOLD DOLLAR, R. $\quad 3 \frac{1}{2} \mathrm{ft}$. Redding. Large hybrid show with beautifully fluted petals. Color golden-bronze, shaded apricotbuff. Flower's very freely and is held very erect on good stems.

$50 \mathrm{c}$

GRAND DUCHESS.

$6 \mathrm{ft}$.

Gill.

Color soft buff, overlaid with orange. The plants are strong growers and require a lot of room to grow.

$25 c$

GOLD MEDAL. $\quad 31 / 2 \mathrm{ft} . \quad$ Keynes.
Color sunflower yellow, oriental that attracts. Blooms of good size, perfect round balls and evenly quilled. Erect on long straight stems.

$25 \mathrm{c}$

GOV. GUILD.

$5 \mathrm{ft}$.

Sheffield

A real good pure white show dahlia, an ideal garden variety as well as for cutting. Perfect round balls.

$25 c$

GOLDEN OPPORTUNITY. $3 \frac{1}{2} \mathrm{ft}$. Doolittle. One of the largest true dahlias. Color buttercup yellow, shaded to burnt orange at the center. A giant flower that stands very erect on strong stems.
HELEN HOLLIS. $\quad 51 / 2 \mathrm{ft}$. Alexander. Undoubtedly the largest and best bright red show dahlia yet introduced. An immense flower that is borne very freely and very erect on long straight stems.

$50 \mathrm{c}$

IVANHOE.

$3 \frac{1}{2} \mathrm{ft}$.

Alexander. An enormous ball-shaped flower on strong stems that hold it perfectly erect. Color pure white, beautifully edged with pinkishlavender. Very free.

$25 c$

JOHN TOZIER. $\quad 51 / 2 \mathrm{ft}$. Dahliadel. Flowers of large size and hybrid show type. Color rich deep lavender.

$50 \mathrm{c}$

LEMON BEAUTY. 5ft. Redding.

One of the freest flowering show dahlias. Color bright lemon.

$20 \mathrm{c}$

\section{LOVELY NELL.}

$4 \mathrm{ft}$.

Redding.

Color crean, shading to pink at the center, a beautiful blending of colors. Excellent variety on good stems.

$35 c$

LUCY FAUCETT.

$5 \mathrm{ft}$.

Saul.

Color pale yellow, spotted and striped with deep pink or magenta. One of the best fancy show dahlias.

$35 c$

MAUD ADAMS. 4ft. Alexander. Undoubtedly one of the finest show dahlias, a model flower. Unsurpassed as a cutting variety, blooming very freely on long stems and keeping a long time after cutting. Color white very effectively overlaid with clear delicate pink. Every one should grow this splendid dahlia.

$35 \mathrm{c}$

MANOMET. $5 \mathrm{ft}$. Redding. A seedling from Gen. Miles which it resembles in size, form and habit of growth, in color a deep rich purple. A giant flower of the hybrid show type.

$75 \mathrm{c}$

MONA. $3 \frac{1}{2} \mathrm{ft}$. Redding. Color a fine deep pink without shading. Large round ball-like flower with tightly quilled petals. Very free.

$25 c$

NORMA. $4 \mathrm{ft}$. Turner. A beautiful colored show dahlia of quite even formation. Color a clear bright orangebuff shade that attracts.

$25 \mathrm{c}$

NEDO. $\quad 3 \frac{1}{2} \mathrm{ft}$. Redding. Color white at the base, changing to lavender and again to magenta at the tips. Large round balls. 
PATSY.
Large round ball-like flower with finely Large round ball-like flower with finely lavender.

$25 \mathrm{c}$

PEGGY.

$4 \mathrm{ft}$.

Redding.

In this new show dahlia we have a new color that is difficult to describe, probably fawn-pink is the nearest, a very beautiful color. The blooms are perfect round balls with very closely quilled petals. .......... 50c

PROSPERO, R. 4ft. Redding. A distinct new novelty that has attracted a lot of attention. Large perfectly formed flowers of the true show type. Very free flowering, erect on long straight stems. Color is best described as mulberry. One of the best.

$50 \mathrm{c}$

SILVA QUARTA. 4ft. Stillman. A giant hybrid show of beautiful form and color. In the center of each petal there is a second petal making a double quilled flower. Color lavender.

$\$ 1.00$

SNOWBALL.

$4 \mathrm{ft}$.

Redding.

Large new pure white show dahlia of the finest form, erect on a perfect stem. Excellent variety for cutting, blooming very freely and a long keeper. About the best pure white show. $50 \mathrm{c}$

TEDDY. $31 / 2 \mathrm{ft}$

Redding. Color light lavender shading gradually to a deep lavender at the tips. Large fine flower. Blooms freely.
THE AM. FLAG.

$31 / 2 \mathrm{ft}$.

Blanc.

Color scarlet tipped white. Very good cutting variety.

$20 \mathrm{c}$

TILLAMOOK.

$31 / 2 \mathrm{ft}$.

Gill.

Large beautifully formed flower with petals very tightly quilled and evenly arranged. Color an exquisite shade of soft pink that is always admired. Quite distinct

$50 \mathrm{c}$

VIVIAN. 3ft. Comstock. One of the most popular shows. Color white, heavily tipped rose violet. A very beautiful contrasting of colors. One of the freest bloomers. $35 \mathrm{c}$

W. W. RAWSON. 3ft. F. F. \& R. Color pure white, overlaid with amethystblue. An old beautiful variety that has always been popular. Erect on good straight stems. $25 \mathrm{c}$

WHITE BALL. $4 \mathrm{ft}$ Redding. Very good pure white of true type. Blooms very freely on good stems. $25 \mathrm{c}$

YELLOW BALL. 4ft. Redding. Perfectly round ball of bright yellow. Blooms freely on good stems. $35 \mathrm{c}$

YELLOW PUFF. $3 \mathrm{ft}$. Redding. Large fine flower of hybrid type, petals cup-shaped. Rigid stems hold its flowers perfectly erect face up. 


\section{Pompon Dahlias}

AILLET'S IMPERIAL. 4ft. Peacock. A very attractive pompon of the finest compact form. Color creamy-white, tipped crimson.

$4 \mathrm{ft}$.

Seale.

AMBER QUEEN. Distinct attractive pompon that is one of
the most popular grown. Its beautiful color, perfect form and long upright stems making an ideal variety. Color rich amber, shaded apricot.

$25 \mathrm{c}$

BAMBINO.

$4 \mathrm{ft.}$

Redding.

Color crimson-red. A new red of the finest form, erect on long straight stems. Fine for cutting, blooming freely.

$35 c$

BABY.

$31 / 2 \mathrm{ft}$.

Redding.

A lovely little flower of small compact form. Color lavender pink to white at the tips. Very small.

$25 \mathrm{c}$

BELLE OF SPRINGFIELD. 2ft. English. The smallest dahlia yet produced, its minature flowers are seldom over one inch in diameter and are always perfection. The plants seldom grow over two feet high but are always loaded with blooms. Color brickred. A perfect little gem.

$25 \mathrm{c}$

BOBBY. $31 / 2 \mathrm{ft}$.

Alexander. Color deep rich plum. The best of its color. Perfect little balls.

$25 \mathrm{c}$

BLONDE.

$4 \mathrm{ft}$.

Redding.

A very choice pompon of distinct color, pure bronze-orange, a wonderful shade. A perfect round ball on upright stems, blooms very freely.

$50 \mathrm{c}$

CLARA HARSH.

$3 \mathrm{ft}$.

White. Color pure yellow, shaded to crimson at the tips. Very good.

$25 \mathrm{c}$

DARKNESS.

$4 \mathrm{ft}$.

Keynes.

The best dark red pompon to date. Stands very erect on long bare stems well above the foliage.

$25 \mathrm{c}$

\section{DAYBREAK.}

$3 \mathrm{ft}$.

Peacock.

Very satisfactory pompon. Color a beautiful clear pink. $15 \mathrm{c}$

GRAUSS AM WEIN. 21/2ft. Cannel. A charming variety that is always admired for its distinct, beautiful color, a lovely crushed strawberry shade.
GOLDEN QUEEN.

$3 \mathrm{ft}$.

Alexander. A grand good yellow pompon, exceedingly neat compact flower on strong, straight stems and exceptionally free flowering. Clear bright yellow.

HENRIETTA.

$21 / 2 \mathrm{ft}$.

Stillman.

One of the very smallest and most beautiful pompons. A perfect little gem. Color yellow tipped bright crimson.

HILDA SEARL.

$3 \mathrm{ft}$.

$35 \mathrm{c}$ A beautiful variety of striking color, clear bright orange. One of the most popular in this class.

$25 \mathrm{c}$

IDEAL.

$4 \mathrm{ft}$.

West. Probably the most perfect pompon of its color, clear light yellow. Its tiny little flower of finest form. Free bloomer. ..... 50 c

JOE FETTE. $3 \mathrm{ft}$. Bessie Boston. The very finest pure white pompon. A perfect model of this type and stands erect on long straight stems.

$25 \mathrm{c}$

KLEINE DOMITEA. $3 \mathrm{ft}$. Dreer. Color yellow-buff, suffused with orange towards the center.

$25 \mathrm{c}$

LADDIE. $4 \mathrm{ft}$.

Turner.

A small compact flower with closely quilled petals. Color light yellow, tipped crimson. Profuse bloomer.

$20 c$

LASSIE.

$31 / 2 \mathrm{ft}$.

West.

Color yellow base with old-rose shadings. A very charming little flower.

$35 \mathrm{c}$

LITTLE BEAUTY. $31 \frac{1}{2} \mathrm{ft}$. Kunzman. Color clear light pink. A perfectly round ball with very closely quilled petals. Distinct and attractive.

$25 c$

LITTLE BELLE. $\quad 31 \frac{1}{2} \mathrm{ft}$. Alexander. An excellent pompon of refined form and attractive color, a lovely shade of mauve. One of the feest flowering pompons, erect on perfect straight stems.

$25 \mathrm{c}$

LITTLE BESSIE. $3 \frac{1}{2} \mathrm{ft}$. Peacock. One of the freest bloomers, erect on long stems for cutting. A perfect ball. Color creamy-white. 
LITTLE JENNIE. $31 / 2 \mathrm{ft}$. Stillman. A fine companion to little Bessie having
the same form and habit of growth, but in color pale primrose yellow. $15 \mathrm{c}$

LITTLE DUFFER. 4ft. Redding. Small variety of distinct color combination, amber and white in varying proportions, From all white to solid amber.

$25 \mathrm{c}$

LITTLE PAL. 4ft. Redding.

Free blooming variety on long stems. Color white tinted pink.

$25 \mathrm{c}$

LITTLE GRETCHEN. 41/2ft. West. A charming little variety, perfect in every way. Color pure white, distinctly tipped bright rose.

$25 \mathrm{c}$

LITTLE HERMAN.

Color deep maroon, tipped white, a very showy little flower.

MIDGET. $3 \mathrm{ft}$.

Stredwick. Color a lovely blending of salmon and peach shades. A tiny little flower of perfect form. One of the best.

$25 \mathrm{c}$

NEATNESS. $2 \frac{1}{2} \mathrm{ft}$.

West.

Color pale salmon shading to cream at the center. Choice little flower that is always admired. Free flowering.

... 25c

NAUTILUS. $21 / 2 \mathrm{ft}$.

Darnell. Color apricot shading to yellow at the center, a beautiful pompon. An excellent variety for cutting.

$25 c$

NELLIE FRAZER. $4 \mathrm{ft}$. West. One of the best pompons, a small compact variety. Color light ground, edged and tipped with bright rose.
NERISSA.

$3 \mathrm{ft}$.

Turner.

Color a beautiful silvery pink that appeals to every one. One of the very finest, a real gem that is always over sold. True stock is hard to get.

$75 \mathrm{c}$

PEE WEE. 2ft. Bessie Boston. One of the smallest pompons. Color soft yellow, the center shaded to brown. $25 \mathrm{c}$

PHOEBE. $3 \mathrm{ft}$ Keynes. Very fine variety of striking color, yellow tipped deep orange.

$25 \mathrm{c}$

RED HEAD. 4ft. Redding. A new red pompon of great merit. Its round ball-like flowers are borne in great profusion all season.

$35 \mathrm{c}$

ROTHAUT. $2 \frac{1}{2} \mathrm{ft}$ Merritt. Fine new red that is perfect in every way. Very small compact flowers on good stems of freest flowering habit. Color deep crimson-scarlet.

$25 \mathrm{c}$

SUNSET. $\quad 2 \frac{1}{2} \mathrm{ft}$ Keynes. Color clear orange scarlet, a very beautiful shade. An unusual fine variety for garden or cutting. $25 \mathrm{c}$

TOM THUMB. $\quad 21 / 2 \mathrm{ft}$ Pelicano. A new pompon of smallest size and finest form. Color garnet-red. ...................... 25c

TOMMY KEITH. 3ft. West. Color crimson with white tips. .............. $25 \mathrm{c}^{\circ}$

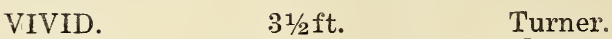
Color vivid scarlet. One of the freest flowering, fine for cutting. $15 \mathrm{c}$

Number of feet following the names, is the average heighth of that variety as grown in my fields.

Names followed with the letter (R) are introductions of my own that have been registered.

Names of originator given where known.

Visitors welcome at all times. Do not fail to see the gardens when in bloom. Usually in bloom from the latter part of July until the middle of October.

When coming from the north or north west inquire for the Long Pond Road at Plymouth, from the south or south west inquire at Buzzards Bay or Bourne for Long Pond road and the same at Sagamore when coming from Cape Cod.

Cut flowers for sale during the blooming season. 


\section{Gladiolus}

ALBANIA. (Kemp) Pure white. Good spike, many open at one time. $15 \mathrm{c}$ ea. $\$ 1.50$ a doz.

ALICE TIPLADY. (Kunderd) Orange-saffron-yellow. Distinct. ... 10c ea. $\$ 1.00$ a doz.

AMERICA. (Betscher) Pinkish-lavender. An old favorite. .................. $5 \mathrm{c}$ ea. $50 \mathrm{c}$ a doz.

ANNA EBERIUS. (Diener) Velvety purple, deeper in the throat. Many blooms open at one time on good spikes. Fine.

$15 \mathrm{c}$ ea. $\$ 1.50$ a doz.

ANNIE LAURIE. (Stevens) White suffused pink, a very dainty flower.

$15 \mathrm{c}$ ea. $\$ 1.50$ a doz.

ANTHONY ZONKER. (Kunderd) Salmonrose, dark blotch in throat. A large flower on long spikes. $20 \mathrm{c}$ ea. $\$ 2.00$ a doz.

BARON HULOT. A medium size flower of rich deep purple. ........... 10c ea. $\$ 1.00$ a doz.

BENGAL TIGER. (Pratt) A giant red, mottled dark slate. Unique. $15 \mathrm{c}$ ea. $\$ 1.50$ a doz.

BLUE TORCH. (Hornberger) Light blue. Tall good spike. ……..... 25c ea. $\$ 2.50$ a doz.

BREAK OF DAY. (Bill) Delicate pink. Fine for cutting. 20 c ea. $\$ 2.00$ a doz.

BYRON L. SMITH. (Kunderd) A delicate lavender-pink on a white ground.

10 c ea. $\$ 1.00$ a doz.

CAPT. BOYNTON. (Boynton) Lavenderblue with dark blotch in throat. One of the most attractive gladiolus. $15 \mathrm{c}$ ea. $\$ 1.50$ a doz.

CARMEN SYLVA. (Pristgard) Pure snowwhite. Fine for cutting. $15 \mathrm{c}$ ea. $\$ 1.50$ a doz.

CATHERINE COLEMAN. (Coleman) Salmon-pink, a beautiful flower of large size. One of the finest.

25 c ea. $\$ 2.50$ a doz.

CHATEAU THIERRY. (Vos) Orange with yellow bordered red blotch. Large fine spike for cutting. 15 c ea. $\$ 1.50$ a doz.

CHOCOLATE DROP. (Kunderd) Light chocolate with deeper shadings.

$10 \mathrm{c}$ ea. $\$ 1.00$ a doz.

COWEE'S SCARLET WONDER. (Cowee)

Bright red. About the largest and best of the red glads.
CRINKLES. (Kunderd) Very bright rose. Beautifully ruffled. ........15c ea. $\$ 1.50$ a doz.

CRIMSON GLORY. (Betscher) A large fine scarlet red. $10 \mathrm{c}$ ea. $\$ 1.00$ a doz.

DIENER'S AM. BEAUTY. (Diener) Rosered with cream throat. $15 \mathrm{c}$ ea. $\$ 1.50$ a doz.

DR. F. E. BENNETT. (Diener) Fiery red. An outstanding variety $15 \mathrm{c}$ ea. $\$ 1.50 \mathrm{a}$ doz.

DR. MOODY. (Kinyon) A beautiful lavender. One of the finest. Fine spike with many open at the same time.

$\$ 1.00$ ea. $\$ 10.00$ a doz.

DR. VAN FLEET. (Kunderd) Rose-pink with yellow throat. ....... $10 \mathrm{c}$ ea. $\$ 1.00 \mathrm{a}$ doz.

E. J. SHAYLOR. (Kunderd) Deep rose-pink. A fine glad.

15 c ea. $\$ 1.50$ a doz.

ELF. (Diener) Creamy white. Large flowers on good spikes.

$10 \mathrm{c}$ ea. $\$ 1.00$ a doz.

ELIZABETH TABOR. (Hinkle) Rose-pink on white ground, dark crimson blotch on the lower petals. Very early.

$10 \mathrm{c}$ ea. $\$ 1.00$ a doz.

EMIL AUBURN. (Lemoine) Copper-bronze, over-laid slate, crimson-red blotch in the throat. Very large. ....... 25c ea. $\$ 2.50$ a doz.

EVELYN KIRKLAND. (Austin) Rose-pink shaded and blotched scarlet.

$15 \mathrm{c} \cdot$ ea. $\$ 1.50$ a doz.

FERN KYLE. (Kunderd) Creamy-white. A beautiful ruffled variety. $15 \mathrm{c}$ ea. $\$ 1.50$ a doz.

GAITY. Light ground with red blotch and markings. Attractive. .... 10c ea. $\$ 1.00 \mathrm{a}$ doz.

GENEVIEVE BOTHIN. (Diener) Plum and blue-gray. Fine new smoky.

$25 \mathrm{c}$ ea. $\$ 2.50$ a doz.

GERALDINE FARRAR. (Diener) Lavender-blue, a lovely variety.

50 c ea. $\$ 5.00$ a doz.

GIANT FAWN. (Kunderd) Fawn-yellow tinted pinkish. Large. $15 \mathrm{c}$ ea. $\$ 1.50$ a doz.

GIANT NYMPH. (Coleman) Rose-pink, creamy-yellow throat. Very large and very beautiful glad. 15 c ea. $\$ 1.50$ a doz. 
GOLD. (Hoeg) Pure golden-yellow: A fine variety. ......................... 10c ea. $\$ 1.00$ a doz.

GOLD DROP. (Kunderd) Deep yellow, red line on the petals. $10 \mathrm{c}$ ea. $75 \mathrm{c}$ a doz.

GOLD EAGLE. (Austin) Clear yellow. Early ruffled variety. .... $25 \mathrm{c}$ ea. $\$ 2.50$ a doz.

GOLDEN MEASURE. (Kelway) Rich cornyellow. A large fine glad, many blooms at one time, fine spike. .... $15 \mathrm{c}$ ea. $\$ 1.50$ a doz.

GOLDEN WEST. Orange-scarlet with dark markings.

$5 \mathrm{c}$ ea. $50 \mathrm{c}$ a doz.

GRETCHEN ZANG. (Austin) LaFrance pink, shaded white. Fine. $10 \mathrm{c}$ ea. $75 \mathrm{c}$ a doz.

HALLEY. (Lemoine) Early salmon-pink. Excellent commercial variety.

$5 \mathrm{c}$ ea. $50 \mathrm{c}$ a doz.

H. C. GOEHL. (Fischer) White with a deep red blotch on the lower petals. Large and very attractive glad. ..... 25c ea. $\$ 2.50$ a doz.

HEAVENLY BLUE. (Pfitzer) The finest blue glad yet introduced. Large size, fine spike and many open flowers at the same time. A wonderful variety.

$\$ 2.50$ each

HENRY FORD. (Diener) Royal purple, an unusual glad. Many flowers open at one time. Fine garden variety.

15 c ea. $\$ 1.50$ a doz.

HEREDA. (Austin) Pure mauve with deeper shading in throat. Quite distinct and attractive. $10 \mathrm{c}$ ea. $\$ 1.00$ a doz.

J. T. PIRIE. (Kunderd) Color mahogany with yellow bordered brown throat. A new novelty of unique color. $25 \mathrm{c}$ ea. $\$ 2.50$ a doz.

LACINATUS. (Kunderd) Rose pink . A small lacinated variety, the first of this type of glad. $10 \mathrm{c}$ ea. $\$ 1.00$ a doz.

LONGFELLOW. (Decorah) LaFrance pink. Large beautiful flower on long spikes. A new attractive variety. $35 \mathrm{c}$ ea. $\$ 3.00$ a doz.

LOS ANGELES. (Houdyshell) Delicate pink with cerese feather in throat. Called the cut and come again glad as it often puts out a second spike. 15 c ea. $\$ 1.50$ a doz.

MARIETTA. (Metzner) Light salmon, shaded to deep burnt orange. Strong grower with fine flower spikes. $15 \mathrm{c}$ ea. $\$ 1.50$ a doz.
MARMORA. (Errey Bros.) Smoky lavender-blue, deeper shadings in the throat. The finest novelty of recent introduction, the best of the smokies. Spikes long with many open flowers at one time. ....\$2.50 each

MARNIA. (Kemp) Beautiful live goldenorange pink. Very large with many open flowers on strong spikes. $20 \mathrm{c}$ ea. $\$ 2.00$ a doz.

MARY FERNELL. (Kunderd) Lavender shaded with pink and yellow throat $5 c$ ea. 50 c a doz.

MING TOY. (Kunderd) Deep orange-buff, distinct, attractive color. $15 \mathrm{c}$ ea. $\$ 1.50$ a doz.

MINUET. (Coleman) A beautiful clear lavender, flowers of the largest size. One of the real wonder glads. ............. $\$ 1.00$ each

MME. VAN KONYNENBURG. (Pfitzer) A stunning new light blue glad. that is proving to be one of the best blue glads. $\$ 1.00$ each

MRS. DR. NORTON. (Kunderd) Creamywhite, edged rose-pink. One of the most beautiful glads grown. $15 \mathrm{c}$ ea. $\$ 1.50$ a doz.

MRS. FRANCES KING. Color orangesalmon. Very satisfactory. $5 \mathrm{c}$ ea. $50 \mathrm{c}$ a doz.

MRS. FRANK PENDLETON. (Kunderd) Light pink, with deep red blotch in the throat. Large well open flower on long spikes. One of the highest rated glads.

$15 \mathrm{c}$ ea. $\$ 1.50$ a doz.

MRS. F. C. HORNBERGER. (Hornberger) About the best pure white. Wonderful spike of large fine blooms. ... 75c ea. $\$ 5.00$ a doz.

MRS. F. C. PETERS. (Fischer) Rosy-lilac, with crimson blotch, fine tall spike. One of the best late glads. ...... $15 \mathrm{c}$ ea. $\$ 1.50$ a doz.

MRS. H. E. BOTHIN. (Diener) Geraniumpink, shaded lighter, flame scarlet center. One of finest and most attractive glads, fine long spikes. $15 \mathrm{c}$ ea. $\$ 1.50$ a doz.

MRS. J. R. WALSH. (Diener) Flesh-pink, lower petals flame, shading to dark ruby at the throat. The flowers are very large and beautifully ruffled. 20c ea. $\$ 2.00$ a doz.

MRS. L. S. SCHWEPPE. (Kundred) Deep peach blossom with velvety rose-red blotches. Not one of the large ones but a very attractive glad. ..... $15 \mathrm{c}$ ea. $\$ 1.50$ a doz. 
MRS. LEON DOUGLASS. (Diener) About the largest, finest and showiest glad. Begonia-rose attractively flaked flame. A real wonder glad.

$15 \mathrm{c}$ ea. $\$ 1.50$ a doz.

MRS. P. W. SISSONS. (Coleman) An out standing variety that will be hard to beat. An immense flower of most beautiful color, light creamy-pink or cameo-pink. Wonderful spike of blossoms. 50c ea. $\$ 5.00$ a doz.

MRS. W. H. PHIPPS. (Diener) LaFrance pink, overlaid salmon-pink. A masterpiece in gladiolus.

35 c ea. $\$ 3.00$ a doz.

NIMROD. (Errey Bros.) Very dark maroon. One of the darkest. $35 \mathrm{c}$ ea. $\$ 3.50$ a doz. OPALESCENT. (Bill) Rosy-lavender. Large fine early variety. $\quad 15 \mathrm{c}$ ea. $\$ 1.50$ a doz.

ORANGE QUEEN. (Pfitzer) Golden-orange A fine large prim. $15 \mathrm{c}$ ea. $\$ 1.50$ a doz.

PERSIA. (Nat. Bulb Farm) Color deep Mahogany red, almost black, the best of this color. Tall fine spike of flowers with many open at one time. $25 \mathrm{c}$ ea. $\$ 2.50$ a doz.

PEACE. (Gand) White with violet featherings on lower petals. ... 10c ea. $\$ 1.00$ a doz.

PFITZER'S TRIUMPH. (Pfitzer) Color orange-salmon, somewhat darker in throat. Large fine spike.

$75 \mathrm{c}$ ea.

PHILATELIA. (Kunderd) A beautiful shade of purple. Large fine spike of flowers. The best of its color.

$\$ 1.50$ each

POLA NEGRI. (Diener) Apricot-orange, with yellow throat. ....... 15c ea. $\$ 1.50$ a doz.

PRINCE OF INDIA. A huge new smokie that is attracting a lot of attention. A wonderful distinct flower. 25c ea. $\$ 2.50$ a doz.

PUREST OF ALL. (Pfitzer) Pure white, very large and fine. ...... 50 ea. $\$ 5.00 \mathrm{a}$ doz.

PURPLE GLORY. (Kunderd) Velvety maroon-red. Shaded to almost black. A nicely ruffled variety of large size. One of the most popular glads. .... $15 \mathrm{c}$ ea. $\$ 1.50 \mathrm{a}$ doz.

PURPLE QUEEN. (Kunderd) Violet-purple, darker in the throat. One of the best of the purple glads.

$25 \mathrm{c}$ ea. $\$ 2.50$ a doz.

PRINCEPINE. Color bright red with distinct white throat, a very striking combination. Excellent for cutting.

$10 \mathrm{c}$ ea. $\$ 1.00$ a doz.
RED COPPER. (Kunderd) Smokie copper, distinct unusual color. $15 \mathrm{c}$ ea. $\$ 1.50$ a doz.

RICHARD DIENER. (Diener) Geraniumpink with cream throat. A large beautiful flower that is well liked. $15 \mathrm{c}$ ea. $\$ 1.50 \mathrm{a}$ doz.

RITA BECK. (Fischer) Beautiful shell-pink. Large and fine.

$\$ 1.00$ each

ROANOAK. Light canary yellow. Very early with a good spike of flowers. Excellent for cutting.

$5 c$ ea. $50 \mathrm{c}$ a doz.

RUTH HUNTINGTON. (Kunderd) Lavender with lilac shadings. A beautiful ruffled variety. Long spikes. ... 15c ea. $\$ 1.50$ a doz.

ROSE ASH. (Diener) Ashes of Roses, a pastel shade. Very tall fine spike. One of the finest glads.

$15 \mathrm{c}$ ea. $\$ 1.50$ a doz.

SARABAND. (Salbach) Rich velvety bordeau with straw-yellow blotch on lower petals, feathered bordeau. Large wide open flower. Distinct. .......... 50c ea. $\$ 5.00$ a doz.

SCHWABEN. A popular yellow, large flower on good spikes. ... 15c ea. $\$ 1.50$ a doz.

SHAMROCK. (Redding) Buds clear green but a mustard green when open. A very small prim. An odd freak.

$25 \mathrm{c}$ ea. $\$ 1.50$ a doz.

SHELL PINK. (Kunderd) Color shell-pink. Large fine flower.

$15 \mathrm{c}$ ea. $\$ 1.50$ a doz.

SIDNEY PLUMMER. (Salbach) Creamyyellow, tinted with pink. Good spike of nicely ruffled flowers. A very satisfactory variety for cutting. ...... $15 \mathrm{c}$ ea. $\$ 1.50 \mathrm{a}$ doz.

SOUVENIR..(Graveau) Pure bright goldenyellow. A very fine early variety. About the purest yellow.

15 c ea. $\$ 1.50$ a doz:

SULPHUR FRILLS. (Kunderd) Sulphuryellow. Petals beautifully frilled. A popular variety.

$15 \mathrm{c}$ ea. $\$ 1.50$ a doz.

TARO. (Kunderd) An American beauty shade with white throat. Very attractive. Fine for cutting. ........... 15c ea. $\$ 1.50$ a doz.

TEMPA (Kunderd) Bronzy old-rose. Strong growing spikes. ........... $10 \mathrm{c}$ ea. $\$ 1.00 \mathrm{a}$ doz.

THE ORCHID. (Sprague) A very interesting new type, orchid shaped and orchid colored. Deeply lacinated.

$50 \mathrm{c}$ ea. $\$ 5.00$ a doz. 
TYCKO ZANG. (Austin) Salmon-pink,
shading to white throat. $15 \mathrm{c}$ ea. $\$ 1.50$ a doz.

VEILCHENBLAU. (Pfitzer) Color deep blue. The finest dark blue grown. Tall fine spike of flowers. $\$ 1.00$ each
VIRGINIA HALE. (Kunderd) Beautiful soft creamy-rose, deeper towards the border. A lovely glad. $15 \mathrm{c}$ ea. $\$ 1.50$ a doz.

WAR. Color crimson-red. One of the best reds for cutting. $10 \mathrm{c}$ ea. $\$ 1.00$ a doz.

VIOLET GLORY. (Kunderd) Purple-violet. WILBRINK. (Hopman) Flesh pink shading Early flowering. ......... $15 \mathrm{c}$ ea. $\$ 1.50$ a doz. to white. Very early. ........5c ea. 50c a doz.

1 dozen Glads. All different, named and labeled. $\quad . \quad$. $\quad . \quad$. . $\quad$. $\$ 1.00$

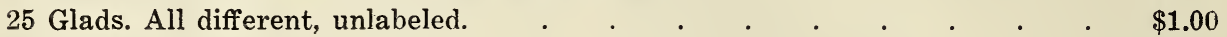

50 Glads. Mixed varieties. . . . . . . . . . . . . $\quad$ : $\$ 1.00$ 



\section{.}

W.

P.XY Y 1. -1.

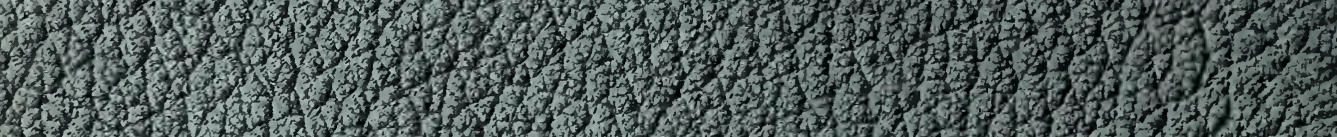
H.1.7,

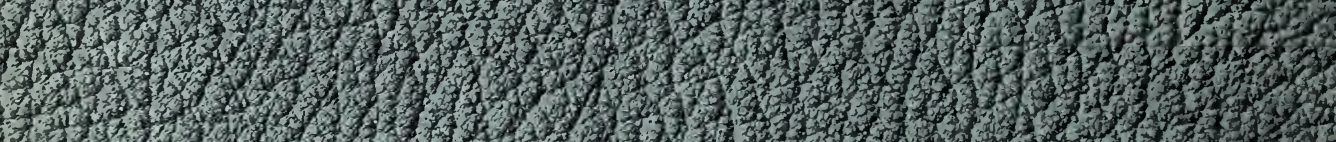
W 1. H.3. W. 13.

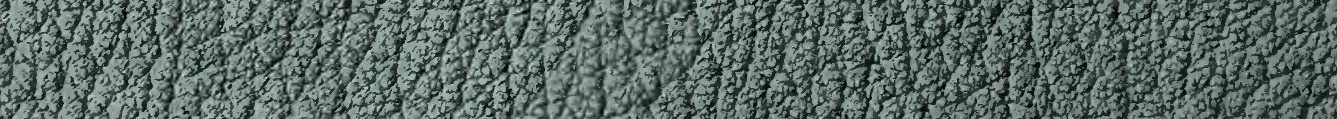

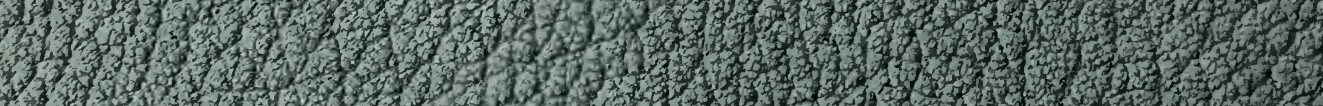

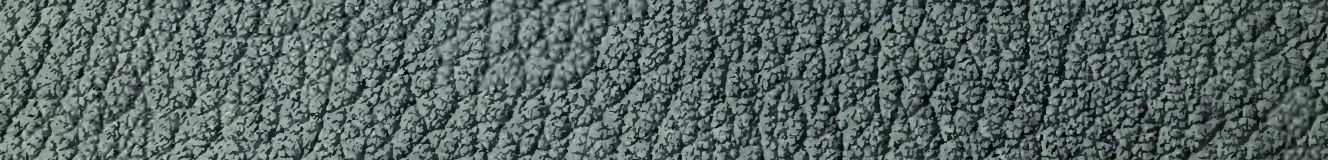
19.7.7.

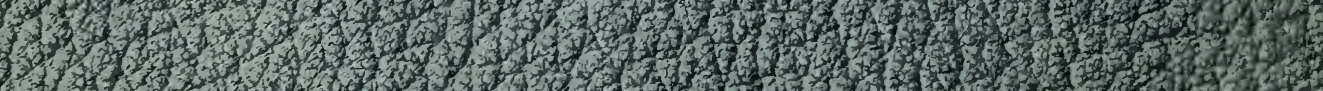

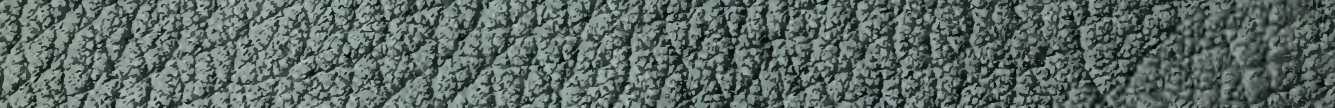

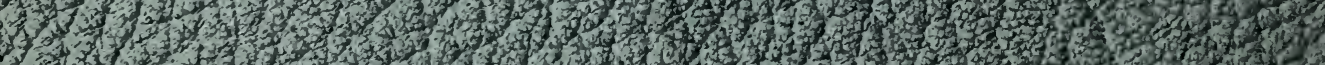

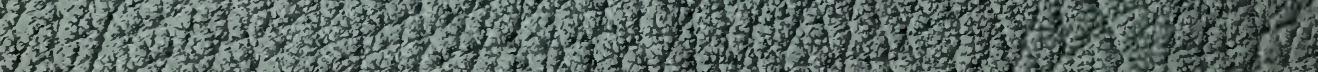

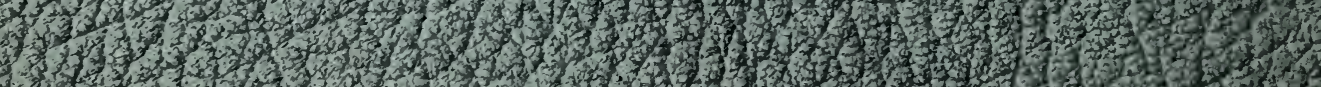

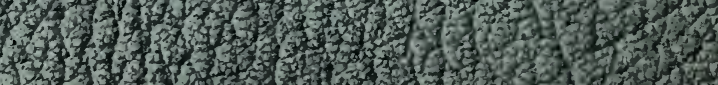

